\title{
EFEITOS DO ULTRA-SOM TERAPÊUTICO NA PREVENÇÃO DE ADERÊNCIAS TENDINOSAS
}

\section{ROSÂNGELA LOBATO}

Dissertação apresentada ao programa de Pósgraduação Interunidades em Bioengenharia / Escola de Engenharia de São Carlos / Faculdade de Medicina de Ribeirão Preto / Instituto de Química de São Carlos, da Universidade de São Paulo, para obtenção do título de Mestre em Bioengenharia.

ORIENTADOR: Prof. Dr. Nilton Mazzer

\author{
Ribeirão Preto
}

2002 


\section{FICHA CATALOGRÁFICA}

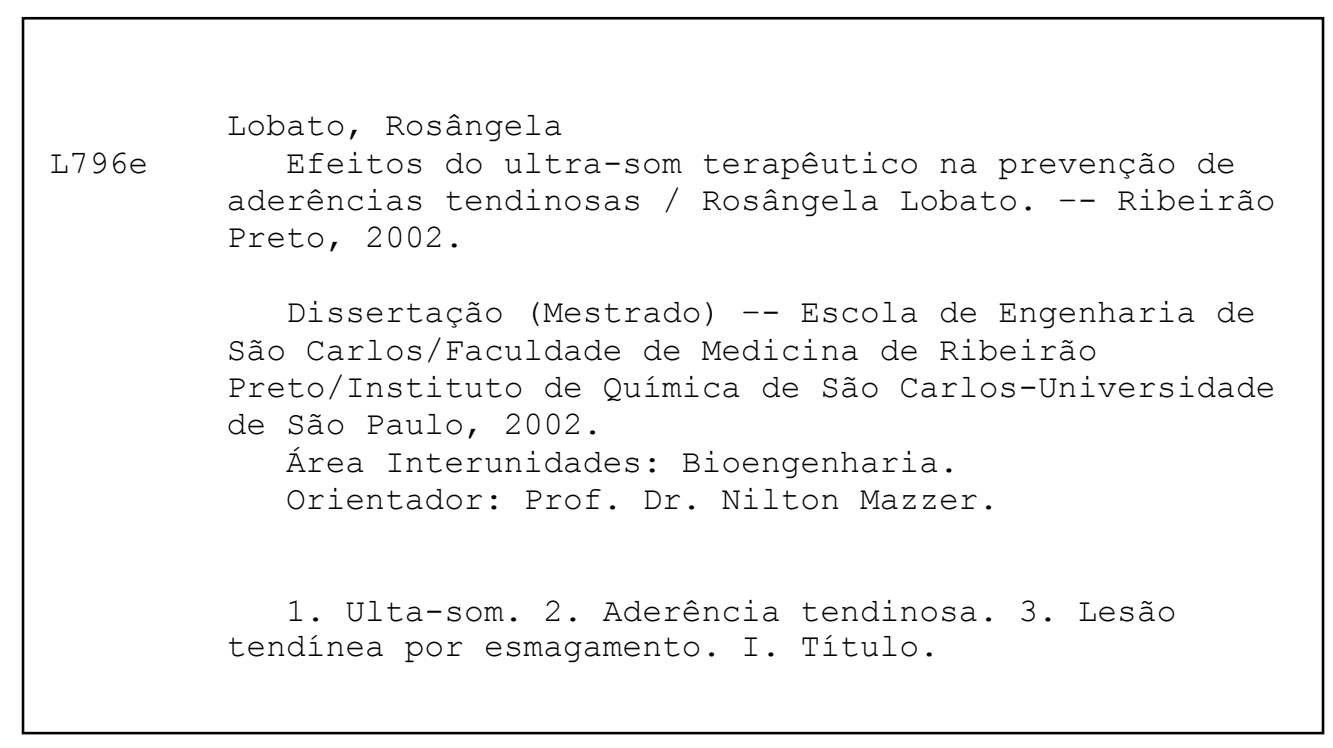


A Deus, pois tenho certeza que em todas as minhas conquistas e dificuldades sou fortemente amparada por suas mãos. À minha família pelo incentivo, amore apoio em todos momentos. 


\section{AGRADECIMENTO ESPECIAL}

Meu agradecimento muito especial ao meu orientador Prof. Dr. Nilton Mazzer pela confiança, orientação, formação científica, amizade e apoio a mim dispensado e pela paciência para a realização deste trabalho. 


\section{AGRADECIMENTOS}

Agradeço a todos que colaboraram com a realização deste trabalho, em particular:

Aos amigos do Laboratório de Bioengenharia: Prof. Dr. José B. Portugal Paulim, Carlos A. Moro, Luís Henrique A. Pereira, Francisco C. Mazzocato, Antonio Carlos Shimano e Maria Terezinha de Moraes, obrigada pela acolhida, amizade, prestatividade e colaboração durante os anos de convivência.

Às amigas da Seção de Reabilitação Neuro-Muscular: Amira, Ana Regina, Haruê, Valéria, Elaine, Elaine Caetano, Adriana Gonçalves, Adriana Barone e em especial à Marisa R. Fonseca pelo incentivo profissional, amizade e colaboração.

Aos amigos e companheiros da Pós-Graduação da Bioengenharia, em especial à Adriana Gonçalves, Adriana Valadares, Vitor Castania, Marcelo Tavares, Marcos Shimano, Carlos Marinheiro, pela ajuda imensa durante todo o tempo de mestrado e sobretudo, à amizade, obrigada.

Às secretárias do Departamento de Biomecânica, Medicina e Reabilitação do Aparelho Locomotor - HCFMRP - USP: Fátima, Elisângela e Rose, pela colaboração.

Às secretárias da Área Interunidade Bioengenharia de São Carlos: Janete e Marielza pela dedicação prestada no atendimento à minha pessoa.

À Dra. Mônica Tempest Pastorello pela valiosa ajuda na interpretação dos achados da microscopia de luz e na documentação fotográfica e à Auristela de Mello 
Martins, pela preparação das lâminas de histologia, ambas do Serviço de Patologia do Hospital das Clínicas de Ribeirão Preto.

Ao engenheiro Carlos A. Moro, idealizador do dispositivo de esmagamento, e aos funcionários da Oficina de Precisão da FMRP - USP, pela montagem do dispositivo de esmagamento.

Ao veterinário Vitor Castania pela orientação da técnica cirúrgica.

Ao Prof. Dr. Picado e ao Prof. Dr. Shimano, pelas valiosas sugestões na Banca de minha qualificação.

E a todos que direta ou indiretamente me ajudaram e contribuíram para a realização deste trabalho, mas que não foram nominalmente citados aqui. 


\section{SUMÁRIO}

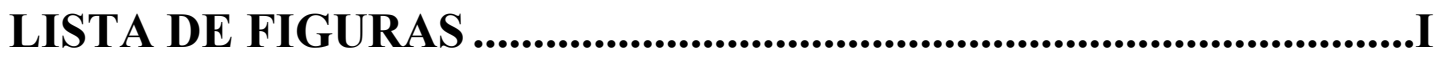

LISTA DE TABELAS .................................................................... III

LISTA DE SIGLAS E ABREVIATURAS.......................................IV

LISTA DE SÍMBOLOS.................................................................................. V

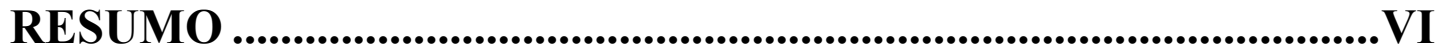

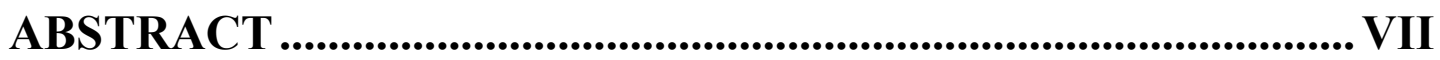

1 INTRODUÇÃ

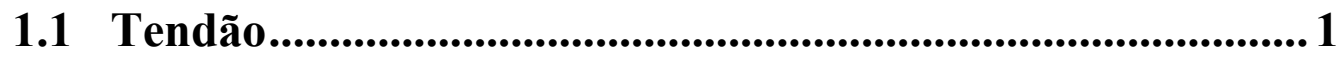

1.2 Cicatrização do tendão ...................................................2

1.3 Formação de aderências.......................................................3

1.4 Lesão do tendão por esmagamento ………………...................... 6

1.5 Ultra-som terapêutico......................................................... 7

1.6 Revisão do estudo da utilização do ultra-som terapêutico 12

1.7 Objetivo............................................................................................... 17

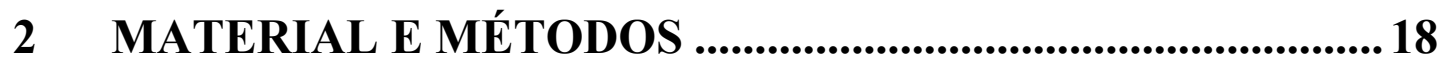

2.1 Animais e ambiente de experimentação ................................. 18

2.2 Dispositivo de esmagamento ...................................................... 18

2.3 Procedimento cirúrgico ........................................................20

2.4 Técnica de imobilização ................................................................23

2.5 Grupos experimentais................................................................... 25

2.6 Tratamento com ultra-som terapêutico...............................25

2.7 Técnica de sacrifício do animal e coleta do material.........27

2.8 Análise histológica........................................................................28

2.9 Análise dos dados ...............................................................28

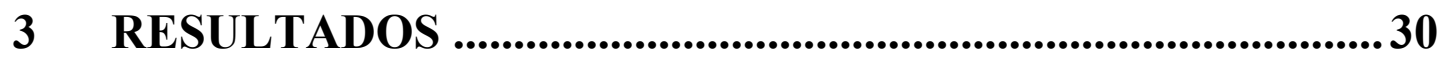

3.1 Generalidades...........................................................................30 
3.2 Análise Histológica..........................................................................30

3.2.1 Grupo A (animais com lesão e tratados - ultra-som com intensidade $\left.0,2 \mathrm{~W} / \mathrm{cm}^{2}\right)$.

3.2.2 Grupo B (animais com lesão e tratados - ultra-som com intensidade de $\left.0,4 \mathrm{~W} / \mathrm{cm}^{2}\right)$................................................................ 31

3.2.3 Grupo C (animais com lesão e tratados - ultra-som desligado) 31

3.3 Grupos A $\left(0,2 \mathrm{~W} / \mathrm{cm}^{2}\right)$ X Grupo B $\left(0,4 \mathrm{~W} / \mathrm{cm}^{2}\right)$............... 38

3.3.1 Variável aderência .................................................................. 38

3.3.2 Variável proliferação de fibroblastos ................................... 38

3.3.3 Variável deposição de fibras de colágeno ................................ 38

3.3.4 Variável células inflamatórias.................................................... 38

3.3.5 Variável microcalcificações........................................................ 39

3.3.6 Variável vascularização ...................................................... 39

3.4 Grupo A $\left(0,2 \mathrm{~W} / \mathrm{cm}^{2}\right)$ X Grupo C (ultra-som desligado) .. 39

3.4.1 Variável aderência ....................................................................... 39

3.4.2 Variável proliferação de fibroblastos ...................................... 39

3.4.3 Variável deposição de fibras de colágeno .............................. 39

3.4.4 Variável células inflamatórias.............................................. 40

3.4.5 Variável microcalcificações.................................................. 40

3.4.6 Variável vascularização ............................................................... 40

3.5 Grupo B (0,4 W/cm²) X Grupo C (ultra-som desligado) .. 40

3.5.1 Variável aderência .................................................................. 40

3.5.2 Variável proliferação de fibroblastos ...................................... 40

3.5.3 Variável deposição de fibras de colágeno .................................. 41

3.5.4 Variável células inflamatórias.................................................... 41

3.5.5 Variável microcalcificações................................................. 41

3.5.6 Variável vascularização ............................................................. 41

3.6 Resultados da demonstração gráfica dos 3 grupos........... 42

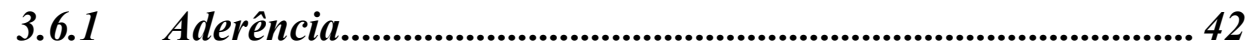

3.6.2 Proliferação de Fibroblastos..................................................... 43 
3.6.3 Deposição de Fibras de Colágeno ............................................. 44

3.6.4 Reação Inflamatória ......................................................... 45

3.6.5 Microcalcificações.............................................................. 46

3.6.6 Vascularização ............................................................... 47

4 DISCUSSÃ

5 CONCLUSÃO ..........................................................................55

REFERÊNCIAS BIBLIOGRÁFICAS..........................................56

ANEXOS 


\section{LISTA DE FIGURAS}

FIGURA 1 - Dispositivo de carga utilizado para o esmagamento.

FIGURA 2 - Exposição do tendão flexor profundo do terceiro dedo da pata dianteira direita, na zona de transição 3 e 4. Seta demonstra o tendão íntegro (A); seta demonstra o tendão com escarificação (B). 22

FIGURA 3 - Técnica de esmagamento: Posicionamento de um animal no dispositivo (A); seta demonstra o tendão com a lesão por esmagamento (B).

FIGURA 4 - Órtese de imobilização (A); seta demonstra o posicionamento da órtese de imobilização em um animal (B).

FIGURA 5 - Aparelho de ultra-som terapêutico (A); seta demonstra o cabeçote reduzido de $5 \mathrm{~mm}$ de diâmetro (B). 26

FIGURA 6 - Ilustração de um animal recebendo tratamento com ultra-som na região onde foi produzido a lesão tendínea.

FIGURA 7 - Microscopia do tendão flexor: As setas demonstram na coloração azulesverdeada a presença de aderência: Ilustração de um animal do grupo A (A); Ilustração de um animal do grupo B (B); Ilustração de um animal do grupo C (C). Mostrando maior presença de aderência no grupo C. Corados por Tricômio de Gomori. Corte longitudinal. Aumento de 100x 32

FIGURA 8 - Microscopia do tendão flexor: As setas demonstram a presença de estruturas alongadas, os fibroblastos: Ilustração de um animal do grupo A (A); Ilustração de um animal do grupo B (B); Ilustração de um animal do grupo C (C). Mostrando maior proliferação de fibroblastos no grupo A. Corados por Hematoxilina Harris/Eosina Floxina. Corte longitudinal. Aumento de 400x.... 33 FIGURA 9 - Microscopia do tendão flexor: As setas demonstram na presença de colágeno: Ilustração de um animal do grupo A (A); Ilustração de um animal do grupo B (B); Ilustração de um animal do grupo C (C). Mostrando maior deposição de fibras de colágeno no grupo C. Corados por Tricômio de Gomori. Corte longitudinal. Aumento de 100x.

FIGURA 10 - Microscopia do tendão flexor: As setas demonstram a presença de células inflamatórias. Ilustração de: um animal do grupo A (A); um animal do 
grupo B (B); um animal do grupo C (C). Mostrando uma maior reação inflamatória no grupo A. Corados por Hematoxilina Harris/Eosina Floxina. Corte longitudinal para A e corte transversal para B e C. Aumento de 400x.... 35 FIGURA 11 - Microscopia do tendão flexor: As setas demonstram a presença de microcalcificações: Ilustração de um animal do grupo A (A); Ilustração de uma animal do grupo B (B). Corados por Hematoxilina Harris/Eosina Floxina. Corte longitudinal. Aumento de 200x. 36

FIGURA 12 - Microscopia do tendão flexor: Vascularização - As setas demonstram a presença da luz de capilares: Ilustração de um animal do grupo A (A); Ilustração de um animal do grupo B (B): Ilustração de um animal do grupo C (C). Mostrando maior presença da variável no grupo C. Corados por Hematoxilina Harris/ Eosina Floxina. Corte transversal. Aumento de 200x..... 37

FIGURA 13 - Comparação dos valores da variável aderência - Histograma ilustrando o comportamento da variável entre os grupos A, B e C.

FIGURA 14 - Comparação dos valores da variável de fibroblastos - Histograma ilustrando o comportamento da variável entre os grupos A, B e C.

FIGURA 15 - Comparação dos valores da variável deposição de fibras de colágeno Histograma ilustrando o comportamento da variável entre os grupos A, B e C.44 FIGURA 16 - Comparação dos valores da variável reação inflamatória - Histograma ilustrando o comportamento da variável entre os grupos A, B e C. 45

FIGURA 17 - Comparações dos valores da variável microcalcificação - Histograma ilustrando o comportamento da variável entre os grupos A, B e C.

FIGURA 18 - Comparação dos valores da variável vascularização entre os grupos A,

$\mathrm{B}$ e $\mathrm{C}$ 


\section{LISTA DE TABELAS}

TABELA 1 - Resultados da variável aderência. .................................................... 42

TABELA 2 - Resultados da variável proliferação de fibroblastos............................ 43

TABELA 3 - Resultados da variável deposição de fibras de colágeno...................... 44

TABELA 4 - Resultados da variável reação inflamatória.......................................... 45

TABELA 5 - Resultados da variável microcalcificações......................................... 46

TABELA 6 - Resultados da variável vascularização. ............................................ 47 


\section{LISTA DE SIGLAS E ABREVIATURAS}

HCFMRP - Hospital das Clínicas da Faculdade de Medicina de Ribeirão Preto

FMRP - Faculdade de Medicina de Ribeirão Preto

USP - Universidade de São Paulo

PO - Pós-operatório

Ltda - Limitada

Et al - Colaboradores

Mm - Milímetros

$\mathrm{KHz}-$ KiloHertz

$\mathrm{W} / \mathrm{cm}^{2}-$ Watts por centímetro ao quadrado

$\mathrm{MHz}$ - Mega Hertz

Kg - Kilograma

mg - Miligrama

$\mathrm{N}$ - Newton 
LISTA DE SÍMBOLOS

$\mathrm{A}^{\mathrm{o}}$ - Angstron

$\%$ - Porcentagem 


\section{RESUMO}

O trabalho realizado estudou experimentalmente os efeitos do ultra-som terapêutico na prevenção de aderências tendinosas e no reparo tendíneo. Foi selecionado para o estudo o tendão flexor profundo do $3^{\circ}$ dedo na transição das zonas 3 e 4 da pata dianteira direita de coelho. Foram utilizados 30 coelhos fêmeas adultas jovens, com peso corporal médio de $2,7 \mathrm{Kg}$, divididos em 3 grupos (A, B e C) de 10 animais, sob anestesia para a produção da lesão no tendão, feita por escarificação com o uso do bisturi e o esmagamento num segmento de $5 \mathrm{~mm}$ de diâmetro, utilizando um dispositivo de carga de $15 \mathrm{Kg}$, durante 10 minutos. As patas foram imobilizadas com órtese de material termoplástico durante todo o período experimental (21 dias). O ultra-som terapêutico foi iniciado no $3^{\circ} \mathrm{PO}$, e continuado por 7 dias consecutivos, com 5 minutos de duração. Foi empregado um ultra-som terapêutico, regulado na freqüência de $3 \mathrm{MHz}$, no modo contínuo, sendo que a intensidade de $0,2 \mathrm{~W} / \mathrm{cm}^{2}$ foi aplicada nos animais do grupo $\mathrm{A}, 0,4 \mathrm{~W} / \mathrm{cm}^{2}$ no grupo $\mathrm{B}$ e ultra-som desligado como placebo no grupo C. No $21^{\circ} \mathrm{PO}$ os animais foram sacrificados, e o tendão submetido à análise histológica. Os resultados foram submetidos à análise estatística e demonstraram que houve uma menor formação de aderência no grupo A. A aceleração do reparo tendinoso foi observada em todos os grupos.

Palavras-chave: Ultra-Som. Aderência tendinosa. Lesão tendinosa por esmagamento. 


\begin{abstract}
The work accomplished studied experimentally the effects of therapeutics ultrasound in prevention of tendon adherences and in tendon repair. The deep flexor tendon of the $3^{\text {rd }}$ finger between zones 3 and 4 of a rabbit's right fore-foot was selected for the study. Thirty young adult female rabbits, with a body weight average of $2.7 \mathrm{Kg}$, divided into 3 groups (A, B, and C) of 10 animals each, were used. The tendon injury was made, under the effect of anesthesia, by reaming with the use of a scalpel, and the $5 \mathrm{~mm}$ diameter crushing was made by the use of a device of $15 \mathrm{Kg}$ load for 10 minutes. The feet were immobilized with orthesis made of thermoplastic material during all the experiment period (21 days). A therapeutics ultrasound, set at the frequency of $3 \mathrm{MHz}$, was applied. The intensity of $0.2 \mathrm{~W} / \mathrm{cm}^{2}$ was applied to the animals of group $\mathrm{A} ; 0.4 \mathrm{~W} / \mathrm{cm}^{2}$ to the group B; and the equipment was off when applied to group $\mathrm{C}$ as a placebo. The therapeutics ultrasound was started in the $3^{\text {rd }}$ PO and kept on for 7 consecutive days, with a duration of 5 minutes. On the $21^{\text {st }}$ day the animals were sacrificed; the tendon was analysed histologically. The results were analysed statistically and showed that there was a minor adherence formation in group A. The acceleration of the tendon repair was observed in all groups.
\end{abstract}

Keywords: Ultrasound. Tendon adherence. Tendon injury by crushing. 


\section{INTRODUÇÃO}

\subsection{Tendão}

Os tendões são estruturas cilíndricas alongadas que conectam os músculos aos ossos e são constituídos por tecido conjuntivo denso modelado (DEFINO, 1988), pouco vascularizados, ricos em fibras colágenas, firmemente agrupadas em feixes paralelos, entre os quais existe uma pequena quantidade de substância fundamental amorfa e de fibroblastos (JUNQUEIRA; CARNEIRO, 1999), e, é composto também por água e elastina. O colágeno confere resistência e força tênsil, a elastina confere elasticidade e a água a capacidade de deformação elástica ao tendão. Os tendões são providos de receptores sensitivos chamados órgãos tendinosos de Golgi.

Cada tendão é envolvido por uma bainha sinovial, produtora do líquido sinovial, importante na cicatrização tendinosa, na lubrificação e na nutrição, sendo nutrido também pelos vasos provenientes do mesotendão e do sistema de vínculos (KLEINERT; SCHEPEL; GILL, 1981). Os tendões flexores da mão são reforçados por polias, que são estruturas que mantém os tendões em contato com o esqueleto das falanges, evitando seu deslocamento no sentido lateral e anterior durante a flexãoextensão dos dedos.

Os tendões flexores profundos dos dedos originam-se na musculatura do antebraço e são divididos em 4 tendões. $\mathrm{O}$ tendão para o indicador é independente, e os tendões para os dedos médio, anular e mínimo estão unidos entre si através de 
conexões tendíneas localizadas em um plano atrás dos tendões superficiais. Estas conexões possuem propriedades viscoelásticas, proporcionando uma capacidade de deslizamento, facilitando o adequado funcionamento com o mínimo de atrito.

\subsection{Cicatrização do tendão}

Após um trauma ou lesão, ocorrem várias modificações estruturais, esta seqüência de eventos tem sido descrito por vários autores.

O processo de cicatrização de tecidos moles necessita de 3 à 4 semanas, e até 8 semanas para a produção e a remodelação do colágeno, para estar apto a suportar e transmitir força e tensão proveniente dos respectivos músculos. Gigante et al. (1996), estudaram a fibrilogênese da cicatrização do tendão de Aquiles no rato, descreveram no processo de cicatrização três fases: a fase inflamatória presente até o $7^{\circ}$ dia após a lesão, era caracterizada por um aumento da permeabilidade vascular com extravazamento de plasma, formação de hematoma, deposição de fibrina e presença de células inflamatórias; a fase proliferativa de fibroblastos, presente entre o período de 7 a 15 ou 20 dias após a lesão, era marcada também pela angiogênese, aparecimento de fibras colágenas com diâmetro maior que 400-600 $\mathrm{A}^{\circ}$ e fibras elásticas imaturas, já a fase reparativa ou de remodelação do tendão, aconteceu a partir do $21^{\circ}$ dia da lesão, é caracterizada por alguns eventos como o aumento e organização da matriz, diminuição do número de células, retorno da vascularização e inervação normal, fibras colágenas com diâmetro de $800-1000 \mathrm{~A}^{\circ}$, aumento na deposição de elastina. Entre a $6^{\mathrm{a}}$ a $8^{\mathrm{a}}$ semanas o aspecto do tendão era normal, porém as fibras colagenosas eram imaturas. 
Quanto ao mecanismo bioquímico da cicatrização do tendão flexor da mão, existem 3 possibilidades: a primeira considera a cicatrização extrínseca, isto acontece somente pela invasão das células provenientes do envoltório extra-tendinoso; a segunda, chamada de intrínseca, observaram a presença de todos os elementos celulares necessários para promoverem a cicatrização, resultando da proliferação celular intra-tendinosa; e, uma terceira mista, em que a cicatrização do tendão ocorre através de uma proliferação celular intra-tendinosa, como pela invasão celular dos tecidos vizinhos, particularmente da bainha sinovial (POTENZA, 1962). Durante estes processos, algumas complicações podem surgir, como aderências tenocutâneas, atrofia muscular, lesão da cartilagem articular, osteoporose, infecção e tromboflebite (ENWEMEKA, 1989 a, 1989b).

Durante o processo de cicatrização, esta pode ser acelerada e as complicações minimizadas com o emprego de agentes físicos e com a utilização de métodos de mobilização precoce (STEVENSON et al., 1986; ENWEMEKA, 1989 a; ENWEMEKA, 1989 b; ENWEMEKA; RODRIGUEZ; MENDONSA, S., 1990; GUM et al., 1997).

\subsection{Formação de aderências}

As aderências podem ocorrer devido ao trauma cirúrgico ou isolada, ela é um sério problema no campo da cirurgia ortopédica, provocando freqüentemente, limitações articulares e prejuízo no mecanismo de deslizamento dos tendões, levando a um mau resultado funcional, especialmente após procedimentos cirúrgicos. Embora 
o mecanismo de formação de aderência ainda não esteja totalmente conhecido, algumas teorias são apontadas como responsáveis pela sua gênese.

Bunnell (1956) aceita que após um trauma ou uma lesão tendinosa, ocorre uma grande quantidade de extravasamento de exsudato serofibrinoso para fora dos tecidos, e se a mão permanecer imobilizada por um período prolongado este exsudato rico em proteína e fibrina se organiza e dificulta o deslizamento das partes moles, e em seguida virá uma proliferação fibroblástica que resultará em aderência tendinosa.

Potenza (1962) considerou a aderência como um fenômeno indesejável, porém necessário ao processo de cicatrização tendinoso, e que o tendão suturado atuava passivamente, não participando da atividade reparadora.

Segundo Ellis (1962), em tecidos lesados a isquemia é um potente estímulo para a formação de aderências.

Peacock (1965) relatou que o tecido de cicatrização tendinoso e das aderências é originário do envoltório extra-tendinoso, e que a cicatrização tendinosa depende unicamente da migração de células para o interior do tendão.

Kessler; Nissin (1969) referiram que lesões parciais ou totais dos tendões desenvolvem uma maciça reação fibrótica, mas uma boa sutura levaria a uma quantidade significativamente reduzida de aderência. Ressaltaram que o movimento precoce poderia mudar o curso natural das aderências e preservar a função fisiológica do tendão.

Matthews; Richards (1976) em seus estudos demonstraram que uma aderência tendinosa secundária à formação da cicatriz, resulta da lesão da bainha, da presença da sutura do tendão e da imobilização pós-operatória. 
Para Watson (1978), um trauma nos tendões flexores de coelhos foi o fator determinante das aderências ao redor do tendão, do que a isquemia.

Pennington (1979) realizou suturas em tendões de galinhas e observou uma quantidade maior de aderências tendinosas no grupo em que a bainha tendinosa era ressecada, e atribuiu importante papel à bainha na prevenção de aderências.

Lundborg; Holm; Myhrage, (1980) estudaram em tendões flexores de cães a importância da bainha sinovial na prevenção de formação de aderências e preconizaram sua reparação após a sutura do tendão. Condenaram a ressecção da bainha, acreditando que tal procedimento aumentava a formação de aderências entre as partes moles vizinhas.

Kang et al. (1990) estudaram a importância do líquido sinovial e da vascularização na cicatrização do tendão. Concluíram que a vascularização estava aumentada durante o processo de cicatrização do tendão. Os tendões cicatrizaram completamente e não foi necessário a reparação cirúrgica das lesões para a prevenção de aderências e rupturas.

Segundo Mattar Jr (1991), a lesão do tendão flexor sempre é acompanhada de alterações da circulação intrínseca e extrínseca que provocam uma perda da vascularização tendinosa. O tendão sofrendo um processo de isquemia, tende a se aderir para roubar nutrição de um leito melhor vascularizado. Este autor acredita que para se obter uma cicatrização do tendão é obvia a necessidade de se manter os cotos coaptados.

Turek (1991) relata que um trauma direto ou uma infecção pode produzir uma mão edemaciada com exsudato serofibrinoso, estimulando a aderência, que impedirá o deslizamento. Assim um tendão aderente à uma área fibrosada e a tecidos 
subnutridos, não deverá ser submetido a manipulações violentas, as aderências podem romper-se, provocando hemorragia e mais aderências.

A hemorragia intra e pós-operatória tem sido apontada como uma das causas de aderência do tendão, provocando maus resultados funcionais. Para prevenir tal problema, coaguladores bipolar são frequentemente utilizados durante a cirurgia para auxiliar uma adequada hemostasia (HATANO et al., 2000).

Fukui et al. (2000), em seus estudos relataram que o desenvolvimento da aderência é iniciada por coágulo que se forma ao redor do local da lesão e também por uma resposta inflamatória, com infiltrado de neutrófilos, seguido por migração de macrófagos, aí os fibroblastos emergem com subsequente deposição de colágeno.

\subsection{Lesão do tendão por esmagamento}

Rothkopf et al. (1991) em estudo experimental sobre a formação de aderência do tendão flexor de cão, provocaram uma lesão padronizada por escarificação e esmagamento do tendão, utilizando o fórceps de Brown- Adson, com uma carga de $10 \mathrm{~N}$, num período de 10 minutos, com fechamento meticuloso da bainha após o procedimento. $\mathrm{O}$ membro permaneceu imobilizado por 3 semanas. Uma forte e visível aderência e disfunção biomecânica do movimento do dedo foram observados.

Menezes; Volpon; Shimano (1997) em seus estudos sobre a aplicação do ultra-som terapêutico em lesão muscular aguda, promoveu uma lesão por esmagamento no músculo reto anterior do quadríceps, utilizando uma pinça hemostática, do tipo Kelly, por 10 segundos. 
Mendonça (2000) estudou a regeneração do nervo ciático de ratos submetidos a à estimulação elétrica após lesão por esmagamento realizada pela máquina universal de ensaios, com uma carga de $15.000 \mathrm{~g}$ por 10 minutos.

\subsection{Ultra-som terapêutico}

O ultra-som terapêutico tem sido usado há muito tempo, para o tratamento de um grande número de patologias ortopédicas, de doenças músculo-esqueléticas de várias etiologias, de trauma, de outras condições clínicas como na cicatrização de úlceras (DYSON; SUCKLING, 1978), no reparo ósseo (DUARTE; XAVIER, 1983), no aumento da circulação sangüínea de tecido isquêmico (HOGAN; BURKE; FRANKLIN, 1982), como recurso antiinflamatório, na cicatrização tendinosa (ROBERTS; RUTHERFORD; HARRIS, 1982; STEVENSON et al., 1986; TURNER; POWELL, 1989; ENWEMEKA, 1989; JACKSON; SCHWANE; STARCHER, 1991; GAN et al.,1995), na regeneração muscular (MENEZES; VOLPON; SHIMANO, 1997), no estímulo à angiogênese (DIONÍSIO, 1998), na cicatrização tendinosa (BARROS JR, 2001; ROMANO, 2001), sobre placa metálica implantada (GARAVELLO et al., 1997), no alívio da dor, na liberação de aderências em articulações e tendões.

Ultra-som é uma forma de energia mecânica que consiste de um movimento vibratório de alta freqüência, na forma de onda, de freqüência acima de $16 \mathrm{KHz}$, estando, acima do limite audível para o ouvido humano (Ter HAAR, 1978, 1987) sendo a sua energia transmitida pelas vibrações das moléculas em meios gasosos, sólidos ou líquidos. 
Para o uso terapêutico, a freqüência média do ultra-som deve variar entre 0,75 a $3 \mathrm{MHz}$. Freqüências altas de $3 \mathrm{MHz}$ são de rápida absorção, específicas para os tratamentos dos tecidos superficiais, e freqüências baixas de1 $\mathrm{MHz}$ penetram mais facilmente e são empregadas para tratamentos de tecidos mais profundos (DOCKER, 1987).

A potência da irradiação ultra-sônica é determinada pela intensidade, que é transmitida pelo transdutor. A baixa intensidade de uma onda contínua ou pulsada tem sido utilizada no tratamento das lesões agudas ou crônicas com o objetivo de aumentar o processo de reparação tecidual. Durante as primeiras 24 e 48 horas após a lesão, a prevenção e/ou redução de edema é uma meta importante. Quando o objetivo for alcançar o efeito terapêutico de analgesia e reparo tecidual, deve ser empregado intensidades baixas (McDIARMID; BURNS, 1987), pois altas intensidades podem interferir negativamente na fibroplasia e na síntese do colágeno, dificultando assim o processo de reparação tendinoso (ENWEMEKA, 1989b; ENWEMEKA; RODRIGUEZ; MENDONSA, 1990).

Uma onda ultra-sônica pode propagar-se de modo longitudinal, transversal ou estacionário. Nas ondas longitudinais, a direção da oscilação é a mesma da direção da propagação da onda, e o movimento de vai e vem das partículas, além do efeito compressivo, pode-se propagar em meios sólidos, líquidos e gasosos. Nas ondas transversais, a oscilação das partículas ocorre na direção perpendicular à propagação da onda, a sua aplicação é importante tanto nos meios sólidos, como o tecido ósseo, pois nos meio líquido e em tecidos moles, as ondas são amortecidas de maneira extremamente rápida. As ondas estacionárias possuem um comportamento diverso das anteriores, parte delas podem propagar-se através dos tecidos e serem refletidas 
numa interface entre meios com impedância acústica diferentes, o que favorecerá o aparecimento de áreas de alta densidade em um ponto específico do tecido. Esta forma ocorre quando as ondas de som forem refletidas de volta de uma interface entre dois meios, como por exemplo, tecido mole e osso ou tecido mole e ar (FUIRINI; LONGO, 1996). A formação dessas ondas será evitada através do movimento contínuo do transdutor (Ter HAAR, 1987). Para a transmissão das ondas ultra-sônicas para o tecido será necessário um meio acoplador, com a função de excluir o ar da região entre o transdutor e o tecido (DOCKER, 1987; WILLIAMS, 1987).

Uma transferência de energia ultra-sônica pode ser realizada pelo método de contato direto ou indireto. No método direto o contato do aplicador será diretamente sobre a área corporal a ser tratada, através do uso de um agente acoplador. O agente mais indicado para o método direto é aquele que possui alta viscosidade e transmissão, com característica de impedância de baixa atenuação, para diminuir a suscetibilidade à formação de bolhas (DOCKER; PATRICK; FOULKES, 1982). Os materiais mais usados para o acoplamento do método direto são os géis e óleos (WILLIAMS, 1987). O método indireto, é realizado subaquático ou através da utilização de um balão cheio de água (McDIARMID; BURNS, 1987; WILLIAMS, 1987). Ele é indicado para emprego nas áreas irregulares, ou quando o bom contato entre o cabeçote e a pele está prejudicado.

O ultra-som pode ser produzido na forma de ondas contínuas ou pulsadas. No modo contínuo a intensidade mantém-se constante, não ocorrendo interrupção na propagação da energia para o tecido irradiado, causando um aquecimento (efeito térmico). $\mathrm{O}$ modo pulsado apresenta breves interrupções na propagação da energia 
(KREMKAU, 1985), e resulta em uma redução do aquecimento tecidual, embora com o mesmo nível de estímulo mecânico, o que permite o uso de uma intensidade mais alta, potencializando os efeitos atérmicos do ultra-som sobre os tecidos (DOCKER, 1987).

A escolha entre o modo contínuo e pulsado depende dos efeitos físicos que se deseja obter e da interação entre o ultra-som e o meio em que será aplicado (McDIARMID; BURNS, 1987).

Os mecanismos físicos pelos quais o ultra-som terapêutico atua nos tecidos biológicos, podem ser classificados em térmicos e atérmicos ou mecânicos (DYSON, 1987; KITCHEN; PARTRIDGE, 1990). A principal ação terapêutica do ultra-som no tecido é a produção do aquecimento controlado dentro deste mesmo tecido (COAKLEY, 1978), estes efeitos estão relacionados com a duração do tratamento, intensidade, freqüência e tipo de onda, coeficiente de absorção (DYSON, 1987), tamanho da área a ser tratada, profundidade do tecido, propriedades de dissipação e resfriamento tecidual.

Os efeitos térmicos são evidenciados através do aquecimento tecidual, e produz um aumento temporário na extensibilidade das estruturas altamente colagenosas, tais como tendão, ligamento e cápsula articular, promovendo uma diminuição da rigidez articular, redução da dor e dos espasmos musculares, uma reação inflamatória suave, e aumento temporário na circulação sangüínea. Os tecidos que possuem um alto teor de proteína como músculos e tendões absorvem mais energia do que os tecidos que possuem um alto teor de gordura (LEHMANN; GUY, 1972). Estes efeitos térmicos ocorrem devido à conversão de energia cinética em energia térmica pelos tecidos. 
A temperatura do tecido deve ser mantida entre 40 e $45^{\circ} \mathrm{C}$, por no mínimo 5 minutos (DYSON, 1987). Temperaturas acima de $45^{\circ} \mathrm{C}$ são prejudiciais aos tecidos (BARNET et al., 1994), devendo serem evitadas através do emprego da técnica deslizante com o ultra-som pulsado ou com uma intensidade média ou baixa (DYSON; SUCKLING, 1978).

Os efeitos atérmicos são a cavitação, o fluxo e o microfluxo acústico (DYSON, 1982). O fluxo, ou corrente acústica, é definido como uma circulação uniforme de fluídos, provocadas pela radiação ultra-sônica. Em pequenas estruturas, como as células, a vibração com movimentos circulatórios microscópicos no campo acústico é denominado microfluxo. É através da corrente acústica que se obtêm os efeitos fisiológicos favoráveis do ultra-som (HOOGLAND, 1989).

Ter Harr (1987) descreve a cavitação como sendo um efeito vibracional de micromassagem, com bolhas de ar presentes no sangue ou fluídos dos tecidos, resultantes das mudanças de pressões no campo acústico, induzidas pelas ondas do ultra-som (DYSON, 1987; BARNETT et al., 1994). A cavitação produzida por ondas pulsadas é benéfica, provocando um efeito antiinflamatório e aumento do fluxo sanguíneo. A cavitação produzida por ondas contínuas pode lesar os tecidos.

Quando estas bolhas se contraem e se expandem, conforme a variação da pressão no campo ultra-sônico, é chamado de cavitação estável, e quando as bolhas fazem grandes excursões em sua oscilação, que culminam em seu colapso, associado a um grande aumento na temperatura e na pressão local, é chamado de cavitação transitória. Portanto, a cavitação estável tem valor terapêutico (LEHMANN; HERRIK, 1953) e a transitória pode ser altamente prejudicial aos tecidos (DYSON, 1987). 
Os efeitos fisiológicos dos mecanismos não-térmicos foram descritos por Dyson (1968, 1982, 1987):

1- degranulação de células de sustentação;

2- alteração na função da membrana celular;

3- aumento dos níveis intracelulares de cálcio;

4- estimulação da atividade de fibroblastos, aumentando a síntese protéica, a angiogênese, a permeabilidade vascular e a tensão elástica do colágeno;

5- liberação de agentes quimiotáxicos e a degranulação celular na fase aguda da lesão.

Dyson et al. (1968)acreditam que os efeitos do ultra-som na fase aguda de uma lesão, pode acarretar uma liberação de agentes quimiotáxicos e a degranulação celular, na fase de proliferação. Assim os fibroblastos seriam estimulados a sintetizar uma maior quantidade de colágeno, favorecendo a formação de um tecido cicatricial mais forte.

\subsection{Revisão do estudo da utilização do ultra-som terapêutico}

Efeitos no reparo do tecido tendinoso:

Roberts; Rutherford; Harris (1982) utilizaram o ultra-som pulsado em tendões flexores de coelhos submetidos à tenorrafia, com freqüência de 1,1 MHz, intensidade de $0,8 \mathrm{~W} / \mathrm{cm}^{2}$, por 5 minutos, 5 vezes por semana, por 6 semanas. Identificaram que os tendões tratados não cicatrizaram totalmente, enquanto que o controle apresentou cicatrização normal. 
Enwemeka (1989b) aplicou o ultra-som contínuo em tendões de Aquiles lesados de coelhos. O tratamento foi realizado com freqüência de $1 \mathrm{MHz}$, com intensidade $1 \mathrm{~W} / \mathrm{cm}^{2}$, por 5 minutos, com 9 aplicações diárias iniciadas no $1^{\circ}$ dia de pós-operatório. Foi observado um aumento significativo na resistência à tração e na capacidade de absorção de energia dos tecidos, além da formação de uma área de secção transversa maior e, segundo o autor, pode indicar um maior conteúdo de colágeno.

Turner; Powell, (1989) estudaram os efeitos do ultra-som na fase inicial do processo de reparo tendinoso, utilizando o método subaquático em tenorrafias de tendões flexores de frangos, iniciando o tratamento no sétimo dia de pós-operatório, utilizando a dosagem de $1 \mathrm{~W} / \mathrm{cm}^{2}$ pulsado com ciclo de trabalho de 1:4, freqüência de $3 \mathrm{MHz}, 3$ vezes por semana, totalizando 15 aplicações durante 5 semanas. Todos os animais permaneceram imobilizados até a terceira semana, sendo sacrificados na sexta semana para o teste, havendo 3 semanas de livre movimentação dos membros operados. Não observaram diferenças significativas na resistência à tração ou amplitude de movimento, concluindo que a aplicação do ultra-som não altera o reparo tendinoso e a formação de aderências.

Em outro estudo, Enwemeka; Rodriguez; Mendonsa, (1990) relataram a aceleração do processo de cicatrização em tendões de Aquiles de coelhos, que foram tenotomizados, imobilizados e irradiados com ultra-som contínuo, na freqüência de $1 \mathrm{MHz}$ e intensidade de $0,5 \mathrm{~W} / \mathrm{cm}^{2}$, por 9 dias consecutivos. Os tendões foram submetidos à ensaios mecânicos de tração que demonstraram o aumento da força de tensão e da capacidade de absorção de energia do lado tratado. 
Barros Jr (2001) estudou os efeitos precoce e tardio do ultra-som pulsado (20\%), sobre o processo de cicatrização de tendões flexores profundo em coelhos, utilizou freqüência de $3 \mathrm{MHz}$, intensidade de $0,8 \mathrm{~W} / \mathrm{cm}^{2}$, durante 7 dias consecutivos, por 6 minutos, iniciado 24 horas após o procedimento cirúrgico. Os resultados, obtidos através da análise histológica, demonstraram uma diminuição da reação inflamatória, menor grau de necrose, aumento na proliferação de fibroblastos e aumento na deposição de fibras de colágeno na fase tardia da cicatrização do tendão, mostrando uma ação positiva do reparo de tendões no período tardio da cicatrização.

Romano (2001) observou os efeitos do ultra-som pulsado no processo de cicatrização de tendões flexores profundo de coelhos, submetidos à tenorrafia, com freqüência de $3 \mathrm{MHz}$ e intensidade de $0,8 \mathrm{~W} / \mathrm{cm}^{2}$, por 6 minutos, durante 7 dias consecutivos, iniciado no $1^{\mathrm{o}}$ dia de pós-operatório. Os resultados não interferiram nas propriedades mecânicas de tração do tendão após 4 semanas de pós-operatório. Também foi observado a formação de aderências cicatriciais no local da lesão, formação esta, maior nos tendões não irradiados, sugerindo que o ultra-som pode ter contribuído para a diminuição na formação excessiva de fibrose e aderências.

Cunha; Parizotto; Vidal (2001) avaliaram os efeitos do ultra-som terapêutico na cicatrização do tendão de ratos após tenotomia. Utilizaram frequência de $1 \mathrm{MHz}$, intensidade de $0,5 \mathrm{~W} / \mathrm{cm} 2$, por 5 minutos, por 14 dias consecutivos, nos modos contínuo, pulsado e com o ultra-som desligado. Os animais foram sacrificados no $15^{\circ}$ dia de PO, e os tendões foram analizados pela microscopia de luz polarizada. Os resultados mostraram que a aplicação do ultra-som contínuo induziu a um retardo no 
processo de cicatrização, e quando utilizada no modo pulsado este acelerou o processo de cicatrização tendinoso na fase precoce.

\section{Efeitos na vascularização:}

Hogan; Burke; Franklin, (1982) investigaram o aumento do fluxo sangüíneo em tecido isquêmico de músculos de ratos, submetidos à aplicação do ultra-som pulsado, na freqüência de $1 \mathrm{MHz}$, com intensidade que variaram de 1,25 a 10,0 $\mathrm{W} / \mathrm{cm}^{2}$, por 5 minutos, em dias alternados, por 1 a 3 semanas. Os resultados demonstraram que houve melhora da circulação sangüínea nas arteríolas com a exposição de intensidade de $2,5 \mathrm{~W} / \mathrm{cm}^{2}$. Concluíram que a estimulação dos músculos esqueléticos provocou ligeira constricção de arteríolas, mas quando eram tratados à longo prazo observaram uma melhora da perfusão do músculo enfraquecido.

Os efeitos do ultra-som na vascularização também foi estudada por Dionísio (1998), que após a lesão do músculo reto femoral em coelhos, usou o ultra-som no modo pulsado 1:2, com freqüência de $1 \mathrm{MHz}$, intensidade de $0,5 \mathrm{~W} / \mathrm{cm}^{2}$, por 5 minutos, iniciado 24 horas após a lesão, por 10 dias consecutivos. Os resultados não demonstraram diferenças significativas na rede vascular, sugerindo que o ultra-som não provoca mudanças no padrão vascular.

\section{Efeitos no reparo do tecido muscular:}

Menezes; Volpon; Shimano (1997) utilizaram o ultra-som pulsado no tratamento das lesões musculares do reto femoral de coelhos, na fase aguda, aplicou freqüência de $1 \mathrm{MHz}$, intensidade $0,5 \mathrm{~W} / \mathrm{cm}^{2}$, por 5 minutos, por 10 dias consecutivos, iniciado no $3^{\circ}$ dia após a produção da lesão. Os resultados, pelo teste mecânico, mostrou que os músculos tratados suportaram maiores cargas e 
deformação máximas, e maiores cargas e deformação no limite de proporcionalidade, sugerindo que o ultra-som beneficiou o processo de reparação.

\section{Efeitos no reparo do tecido nervoso:}

Mourad et al. (2001) estudaram os efeitos da ação do ultra-som terapêutico na regeneração do nervo ciático de ratos submetidos à esmagamento. Empregaram vários tipos de tratamento com mudança nos parâmetros de frequência, intensidade e duração, com aplicações em 3 dias por semana, conduzidos 30 dias. Concluíram que a aplicação do ultra-som na intensidade de $0,25 \mathrm{~W} / \mathrm{cm}^{2}$, frequência de 2,25 MHz, por 1 minuto acelerou a recuperação do nervo.

Monte Raso (2002) estudou a influência do ultra-som terapêutico na regeneração do nervo ciático de ratos, submetidos à esmagamento. Utilizou o ultrasom pulsado (1:5), frequência de $1 \mathrm{MHz}$, intensidade de $0,4 \mathrm{~W} / \mathrm{cm}^{2}$ por 2 minutos. Os resultados mostraram que o ultra-som acelerou a regeneração nervosa.

\section{Efeitos no reparo do tecido subcutâneo:}

Popspisilova (1976) verificou a ação do ultra-som, no modo contínuo, com freqüência de $0,8 \mathrm{MHz}$, intensidade de $1 \mathrm{~W} / \mathrm{cm}^{2}$, por 5 minutos, nas fases agudas (2 a 21 dias) e crônica (16 a 35 dias), em síntese de colágeno de granuloma subcutâneos experimental em ratos. Obteve resultados semelhantes, com a diminuição no conteúdo protéico e na síntese de colágeno, na zona em reparação.

Dyson; Suckling (1978) utilizaram o ultra-som pulsado em úlceras varicosas bilateralmente, um lado tratado e o outro não. $\mathrm{O}$ tratamento foi aplicado com freqüência de $3 \mathrm{MHz}$, intensidade de $1 \mathrm{~W} / \mathrm{cm}^{2}$, por 4 semanas, com aplicações de 5 a 10 minutos. Os resultados demonstraram que houve uma redução significante nas áreas que receberam o estímulo em relação ao placebo. 
Efeitos no tecido ósseo:

Duarte; Xavier (1983) comprovaram experimentalmente em animais e em pacientes, que o ultra-som de baixa intensidade estimulou a neoformação óssea e acelerou a consolidação óssea de fraturas ósseas.

\subsection{Objetivo}

O objetivo foi estudar em tendões flexores de coelhos submetidos à lesão por esmagamento a formação de aderências tendinosas e o reparo tecidual, após a aplicação precoce de terapia ultra-sônica, através da análise morfológica. 


\section{MATERIAL E MÉTODOS}

\subsection{Animais e ambiente de experimentação}

Este trabalho foi realizado no Laboratório de Bioengenharia da Faculdade de Medicina de Ribeirão Preto da Universidade de São Paulo.

Selecionou-se o modelo animal que foi o coelho fêmea albino da linhagem Nova Zelândia, adultas, com idade superior a 120 dias, pesando em média $2.7 \mathrm{~kg}$, fornecidas pelo Biotério Central da Prefeitura do Campus da USP-Ribeirão Preto, sendo alimentadas com ração padronizada do Biotério Central. O acesso à água e à alimentação foi igual para todos. Os animais foram mantidos em gaiolas individuais.

Previamente ao procedimento os animais foram pesados e identificados.

\subsection{Dispositivo de esmagamento}

Para a técnica de esmagamento do tendão foi elaborado na Oficina de Precisão da FMRP - USP, um dispositivo da aplicação de carga, substituindo a máquina universal de ensaios utilizada em trabalhos semelhantes tornando o procedimento de esmagamento mais rápido e fácil (FIGURA 1). Este dispositivo consiste de:

a) uma base de apoio para todo o sistema;

b) de um braço de alavanca usado para afastar o aplicador de carga; 
c) de um suporte de apoio fixo para o esmagamento;

d) de uma ponteira que aplica a carga diretamente no tendão, sobre uma base pequena de apoio fixo;

e) de um aplicador de carga com uma mola interna, que foi previamente calibrada em 15 kg para permitir o esmagamento do tendão;

f) o aplicador de carga tem em sua extremidade superior uma manopla, que deve ser girada manualmente, comprimindo a mola interna, e desta forma, atingindo os $15 \mathrm{~kg}$ de carga.

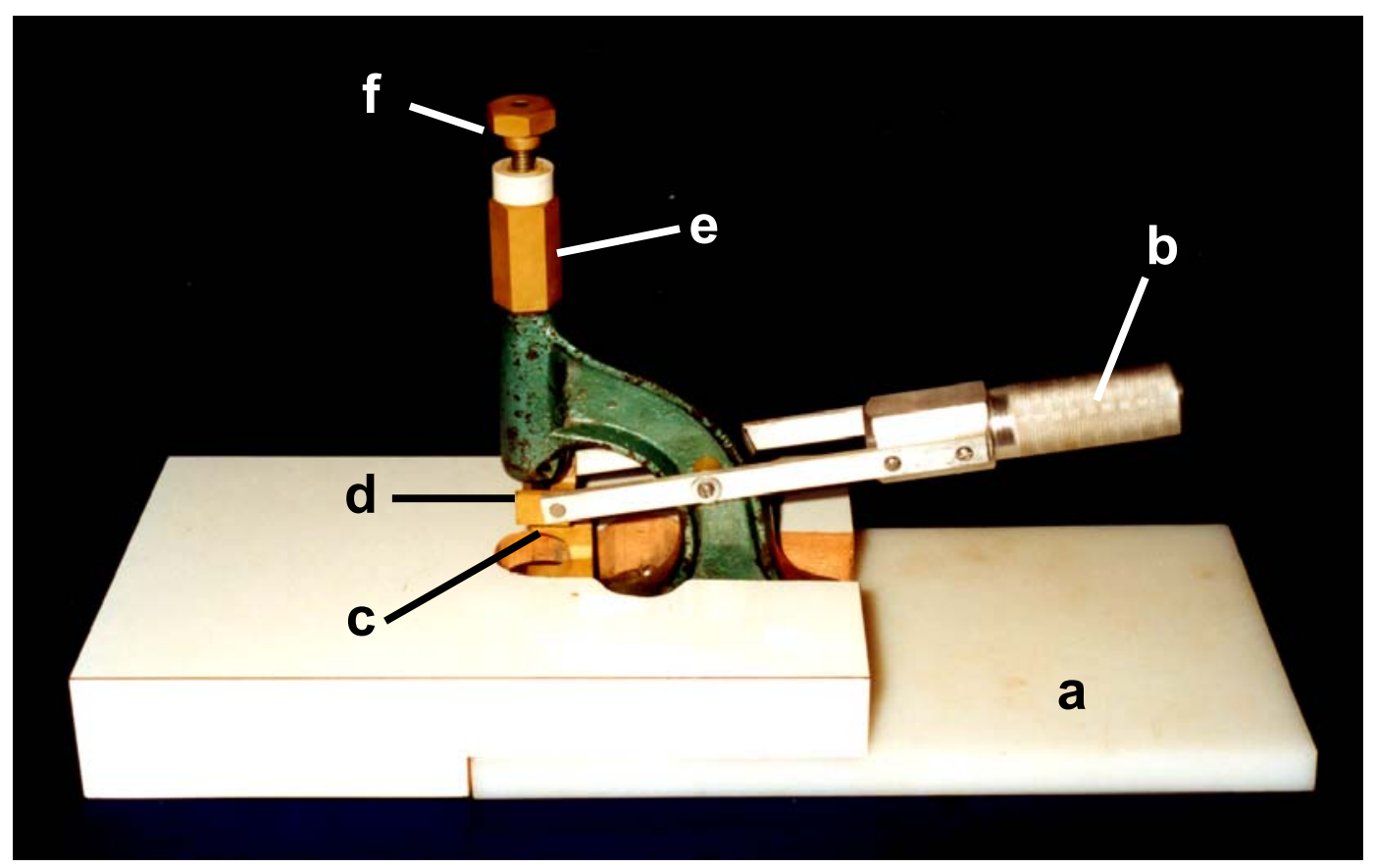

FIGURA 1 - Dispositivo de carga utilizado para o esmagamento.

O dispositivo foi calibrado periodicamente por uma célula de carga, e não foi registrado nenhuma queda da pressão da mola. 


\subsection{Procedimento cirúrgico}

Todos os animais foram submetidos ao esmagamento do tendão flexor profundo do $3^{\circ}$ dedo da pata dianteira direita, entre as zonas 3 e 4 . Para a realização do procedimento, os animais foram anestesiados com Tiopental Sódico (Nembutal ${ }^{\circledR}$ ), diluição de 1,0 g em $50 \mathrm{ml}$ de soro, com uma dose de $4 \mathrm{mg} / \mathrm{Kg}$ de peso corporal, na veia marginal de uma das orelhas, e após procedeu-se a tricotomia e anti-sepsia da pele na face palmar da pata com álcool iodado à $4 \%$ e anestesia local com $0.5 \mathrm{ml}$ de Cloridrato de Lidocaína a 1\%. Doses adicionais de anestésico foram administradas durante o procedimento cirúrgico, conforme os reflexos do animal, para manutenção da anestesia. O procedimento realizado foi o seguinte:

1. Posicionamento do animal na mesa cirúrgica em decúbito lateral direito, com fixação do punho e dedos da pata dianteira em um suporte de madeira em extensão, com elásticos e restrição do outro membro superior;

2. Anti-sepsia com solução de álcool iodado a $20 \%$;

3. Colocação de um campo cirúrgico fenestrado;

4. Incisão longitudinal retilínea cutânea sobre a face palmar, no trajeto entre a zona 3 e 4, e dissecção do tecido subcutâneo, até a exposição do tendão flexor profundo do $3^{\circ}$ dedo;

5. Exposição do tendão flexor profundo do $3^{\circ}$ dedo (FIGURA 2A);

6. Realizado escarificação do tendão utilizando a lâmina bisturi (FIGURA 2B);

7. Posicionamento do animal no dispositivo de esmagamento, o tendão foi apoiado em uma base de metal, ficando então, pinçado entre dois elementos (FIGURA 
3A). A carga estática de $15 \mathrm{Kg}$ foi aplicada de maneira contínua e uniforme, incidindo num segmento de $5 \mathrm{~mm}$ de comprimento, por 10 minutos. $\mathrm{O}$ tendão foi, então, completamente esmagado (FIGURA 3B);

8. Durante o esmagamento, em intervalos regulares foi feito gotejamento de soro fisiológico no tendão;

9. Após o esmagamento o tendão foi cuidadosamente retirado do dispositivo e deixado em seu trajeto de origem;

10. Sutura simples do tecido cutâneo com fios de mononylon 4.0;

11. A ferida foi lavada com álcool iodado a $20 \%$;

12. Administração intramuscular de 200 mil unidades de Penicilina associado à Estreptomicina após o procedimento cirúrgico (dose única). 


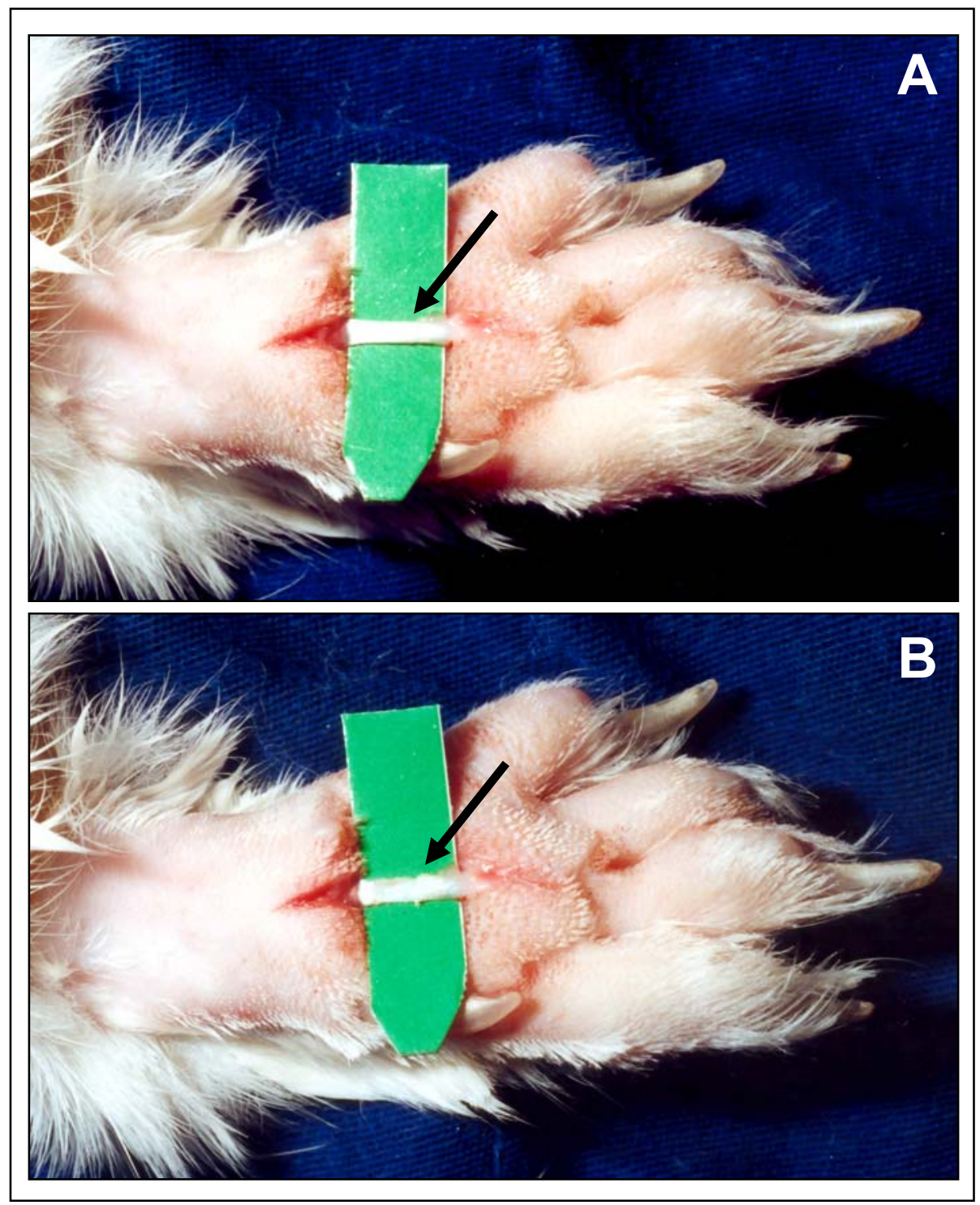

FIGURA 2 - Exposição do tendão flexor profundo do terceiro dedo da pata dianteira direita, na zona de transição 3 e 4 . Seta demonstra o tendão íntegro (A); seta demonstra o tendão com escarificação (B). 

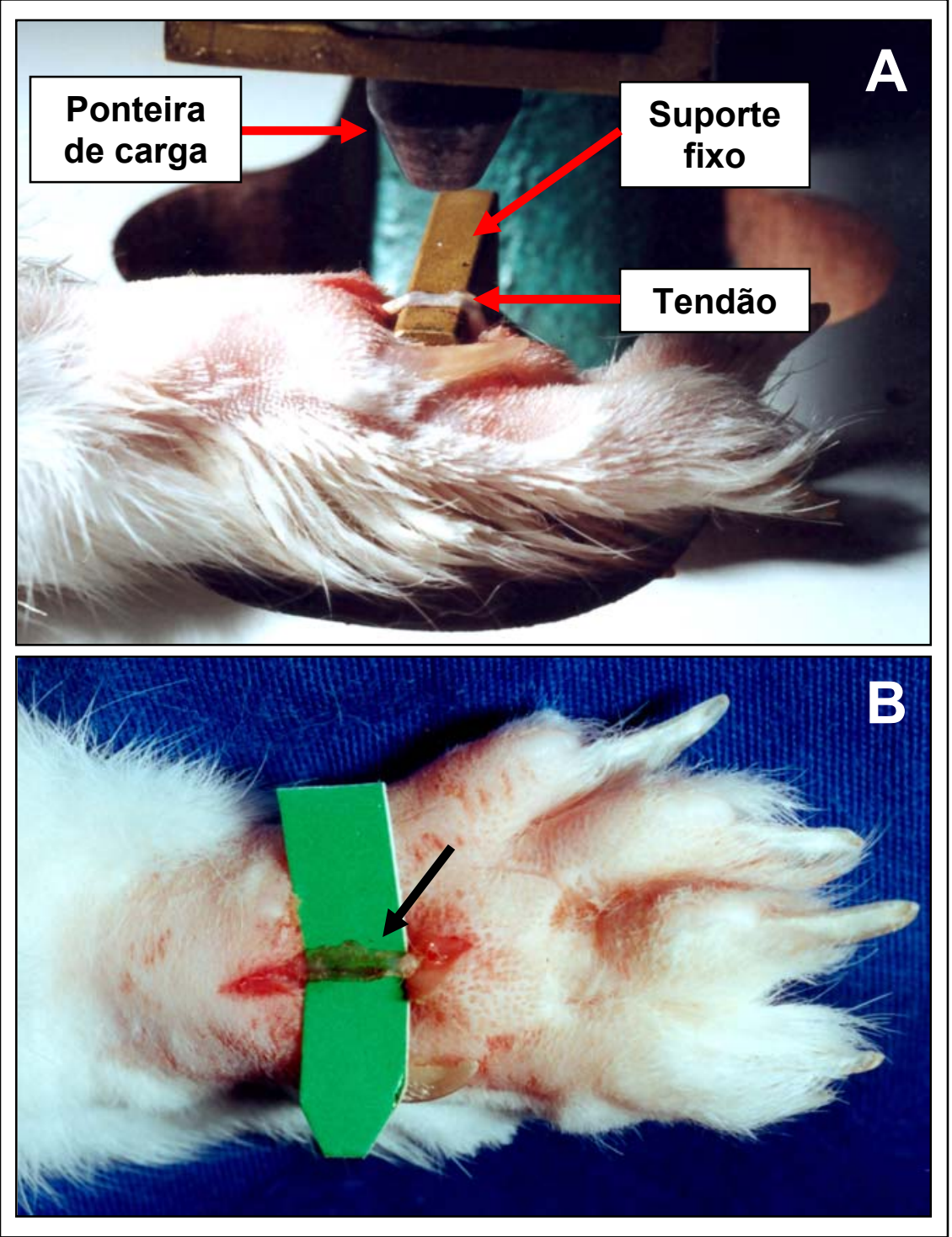

FIGURA 3 - Técnica de esmagamento: Posicionamento de um animal no dispositivo (A); seta demonstra o tendão com a lesão por esmagamento (B).

\subsection{Técnica de imobilização}

Após o procedimento cirúrgico, as patas foram imobilizadas com uma órtese de material termoplástico, previamente confeccionada, mantendo o punho e as articulações metacarpianas e interfalangeanas em flexão (FIGURA 4). A órtese foi 
fixada com a ajuda de fechos de velcro e esparadrapos, permanecendo por 21 dias, e retirados somente após o sacrifício do animal.
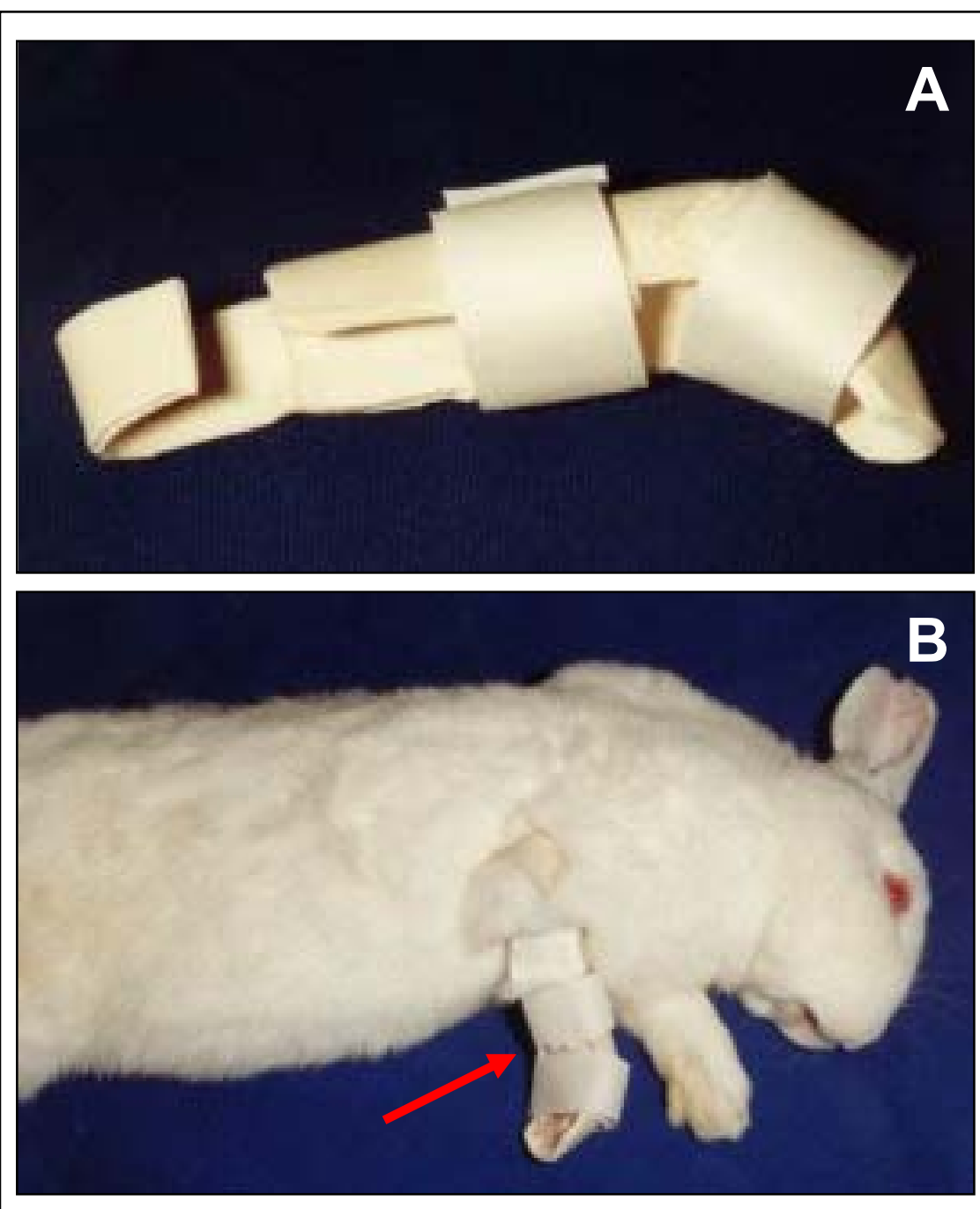

FIGURA 4 - Órtese de imobilização (A); seta demonstra o posicionamento da órtese de imobilização em um animal (B). 


\subsection{Grupos experimentais}

Após o procedimento cirúrgico, os 30 animais foram divididos em 3 grupos: Grupo A: coelhos com lesão, tratados com ultra-som terapêutico, com freqüência de $3 \mathrm{MHz}$, no modo contínuo, intensidade de $0,2 \mathrm{~W} / \mathrm{cm}^{2}$, por 5 minutos, durante 7 dias consecutivos, iniciados no $3^{\circ} \mathrm{PO}(\mathrm{n}=10)$.

Grupo B: coelhos com lesão, tratados com ultra-som terapêutico, com freqüência de $3 \mathrm{MHz}$, no modo contínuo, intensidade de $0,4 \mathrm{~W} / \mathrm{cm}^{2}$, por 5 minutos, durante 7 dias consecutivos, iniciados no $3^{\circ} \mathrm{PO}(\mathrm{n}=10)$.

Grupo C: coelhos com lesão, tratados com ultra-som desligado, por 5 minutos, durante 7 dias consecutivos, iniciados no $3^{\circ} \mathrm{PO}(\mathrm{n}=10)$.

\subsection{Tratamento com ultra-som terapêutico}

O equipamento utilizado na aplicação foi o Ultra-som terapêutico portátil, Sonacel Plus ${ }^{\circledR}$, modelo S. 1050 , Bioset - Industria de Tecnologia Eletrônica Ltda (FIGURA 5A), de uso corrente no tratamento de humanos, dotado de um cabeçote para aplicação da irradiação ultrassônica especialmente confeccionado, de $5 \mathrm{~mm}$ de diâmetro, para melhor acoplamento em áreas pequenas (FIGURA 5B).

Antes de iniciar as aplicações, o aparelho foi calibrado com um dosímetro de precisão (Ultra Sonic Power Meter ${ }^{\circledR}$, modelo UPM-DT-1), no Laboratório de Bioengenharia de São Carlos da Universidade de São Paulo. 
No terceiro dia após a produção da lesão, foi iniciado a aplicação diária de ultra-som terapêutico, durante 7 dias consecutivos. O ultra-som foi aplicado pelo método direto, com movimentos circulares e uniformes ao redor da incisão. Foi utilizado um gel hidrossolúvel como meio acoplador do transdutor, para assegurar a transmissão das ondas para a pele do animal.

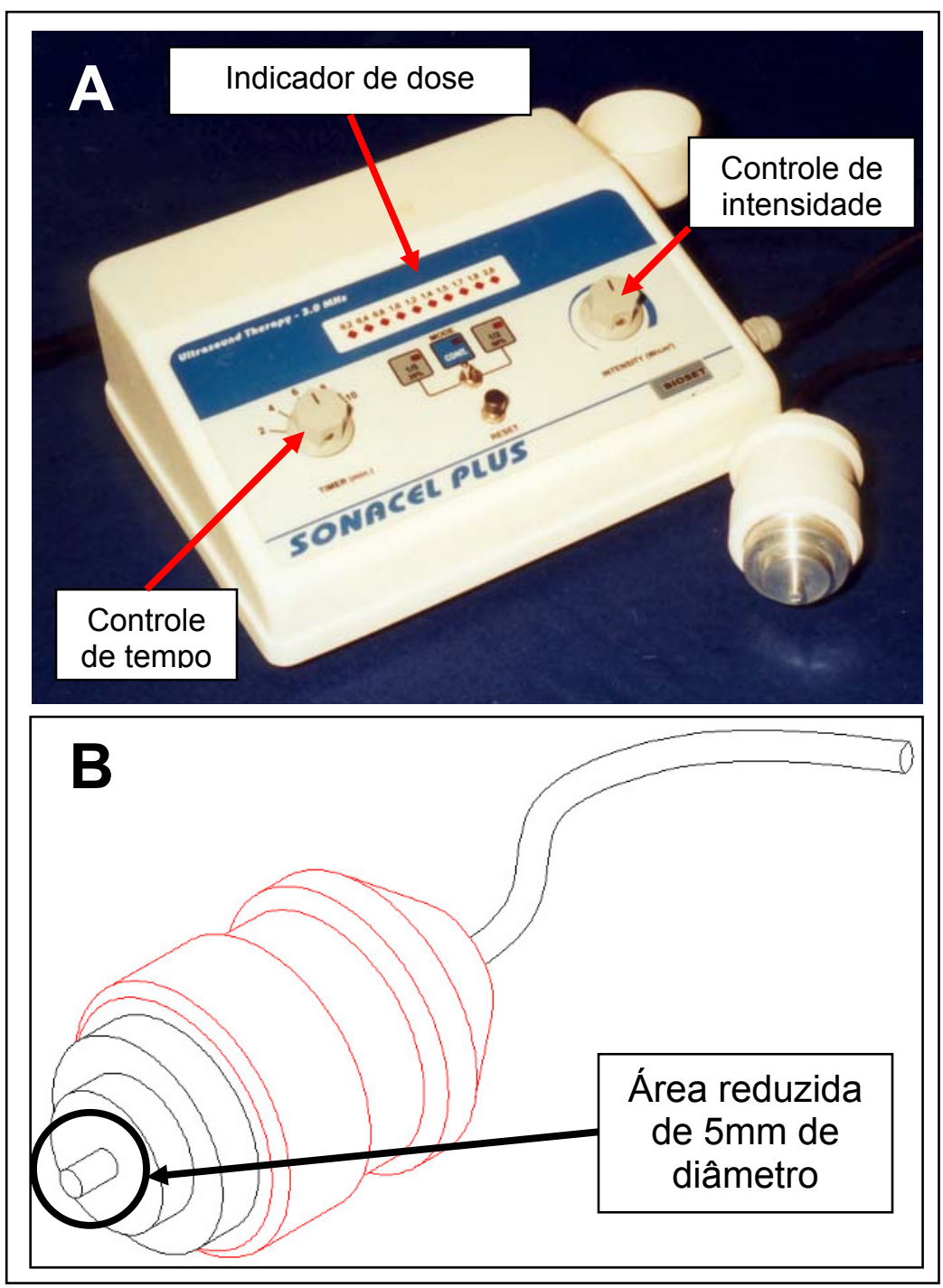

FIGURA 5 - Aparelho de ultra-som terapêutico (A); seta demonstra o cabeçote reduzido de $5 \mathrm{~mm}$ de diâmetro (B). 
Para a aplicação do ultra-som, os animais foram colocados em decúbito lateral esquerdo, contidos nesta posição com a ajuda de outra pessoa, com imobilização as cinturas pélvica e escapular. Não foi necessário a remoção das órteses para a aplicação do ultra-som, pois a área a ser irradiada permaneceu exposta (FIGURA 6). Durante todo o tratamento os animais permaneceram despertos.

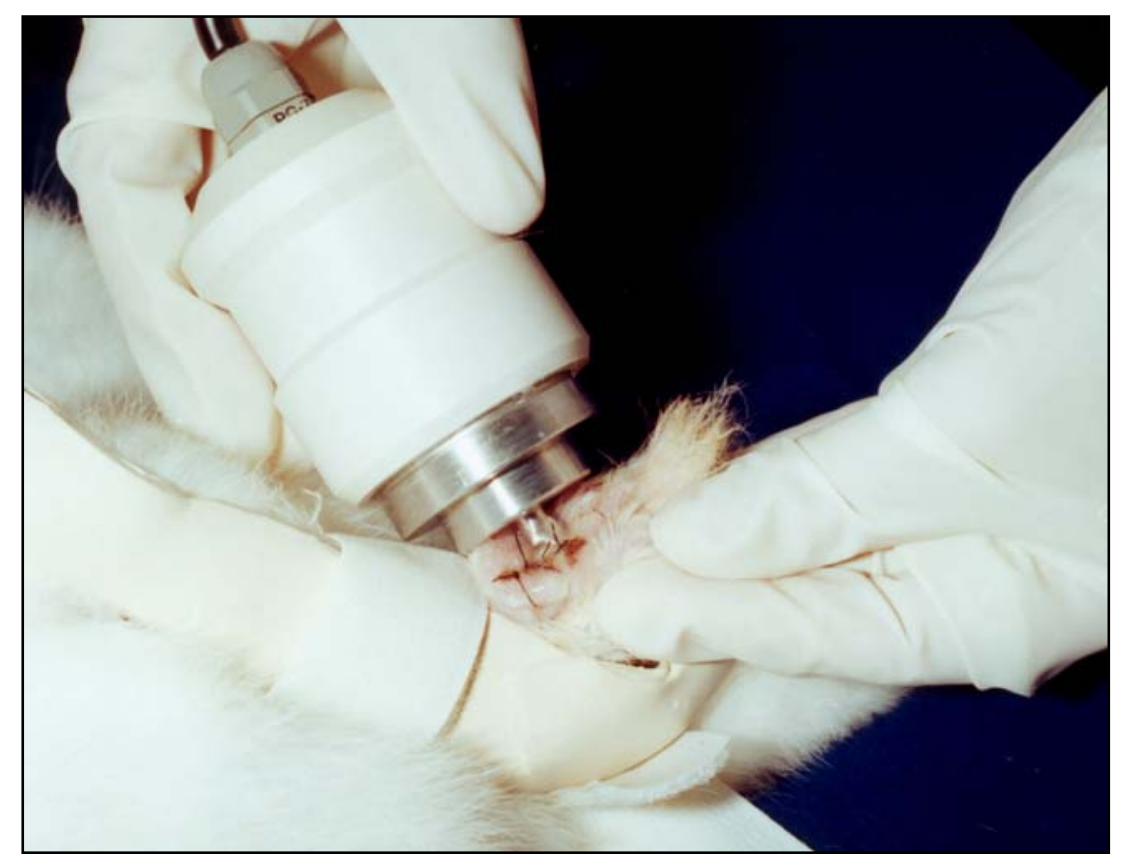

FIGURA 6 - Ilustração de um animal recebendo tratamento com ultra-som na região onde foi produzido a lesão tendínea.

\subsection{Técnica de sacrifício do animal e coleta do material}

Após 21 dias da realização do procedimento de esmagamento do tendão, os animais foram sacrificados por meio de uma injeção intravenosa com uma dose excessiva de Tiopental, então, procedendo-se a desarticulação do membro, na altura 
do cotovelo, retirando-se a pele e permanecendo a peça inteira, sendo colocado em solução de formol a 10\% para posterior análise histológica.

\subsection{Análise histológica}

O membro foi dissecado e após, realizado a descrição, desidratação, difusão do tecido com xilol e impregnação por meio de parafina, inclusão e microtomia. Foram realizados cortes longitudinais e transversais no local da lesão, sendo obtidos cortes de 5 micras, corados por Hematoxilina Harris/Eosina-Floxina e Tricômio de Gomori.

As amostras foram analisadas pela microscopia de luz e os resultados registrados por uma análise semiquantitativa de presença de aderência, de proliferação de fibroblastos, da vascularização, da deposição das fibras de colágeno, de células inflamatórias, de microcalcificações, de condrócitos, de tecido de granulação e do grau de necrose.

Os graus variaram de ausente (0), presença leve (1), presença moderada (2), presença acentuada (3), para a análise da aderência, da proliferação de fibroblastos, da deposição de colágeno e da reação inflamatória; ausente (0) e presente (1) para a análise de microcalcificações; normal (0), presença aumentada (1) e aumentada (2) para análise da vascularização.

\subsection{Análise dos dados}


Para a análise dos dados da histologia, os valores numéricos anteriormente expostos através de cada variável foram comparadas entre os grupos de tratamento e controle.

O teste não paramétrico de Mann-Whitney foi utilizado considerando o nível de significância de 5\% $(\mathrm{p}<0,05)$.

Para as variáveis condrócitos, tecido de granulação e necrose, os resultados foram ausentes (0) em todos os 3 grupos, não sendo incluídos nos resultados. 


\section{RESULTADOS}

\subsection{Generalidades}

Foram operados 39 animais, destes foram utilizados 30, pois 9 foram excluídos do estudo por terem apresentado intercorrências no período de realização dos experimentos (morte - 1 , infecção da cicatriz cirúrgica - 3, retirada dos pontos e da órtese de imobilização -5).

O grupo final de 30 animais foi submetido a avaliação utilizando a microscopia de luz com objetivo de detectar presença de aderências, de proliferação de fibroblastos, de deposição de fibras de colágeno, de células inflamatórias, de microcalcificações e de vascularização.

Os resultados obtidos foram submetidos a análise estatística através da aplicação do teste não paramétrico de Mann- Whitney. Este teste comparou a distribuição dos valores de cada variável entre os grupos de tratamentos e controle, com valores individuais de cada animal (anexos A, B, C, D, E e F).

\subsection{Análise Histológica}




\subsubsection{Grupo A (animais com lesão e tratados - ultra-som com intensidade} $\left.0,2 \mathrm{~W} / \mathrm{cm}^{2}\right)$

Neste grupo, o aspecto do tendão era normal, com presença de pequena quantidade de aderência tendinosa. Observamos ainda a presença discretamente aumentada de fibroblastos, uma deposição normal de fibras de colágeno, discreta presença de células inflamatórias em alguns animais, formação de microcalcificação em apenas um animal e uma vascularização normal (FIGURA 7, 8, 9, 10, 11, 12 A).

\subsubsection{Grupo B (animais com lesão e tratados - ultra-som com intensidade de $\left.0,4 \mathrm{~W} / \mathrm{cm}^{2}\right)$}

Neste grupo, o aspecto do tendão também era normal, com presença de uma moderada quantidade de aderência do tendão, uma presença moderada para leve de fibroblastos, uma deposição normal de fibras de colágeno, discreta presença de células inflamatórias em alguns animais, formação de microcalcificação em apenas dois animais e uma vascularização normal (FIGURA 7, 8, 9, 10, 11, 12 - B).

\subsubsection{Grupo C (animais com lesão e tratados - ultra-som desligado)}

Neste grupo, também foi observado o aspecto normal do tendão, a presença acentuada de aderência tendinosa, uma proliferação normal de fibroblastos, uma deposição maior de fibras de colágeno, discreta presença de células inflamatórias em alguns animais, não foi observado a formação de microcalcificação e uma vascularização discretamente aumentada (FIGURA 7, 8, 9, 10, 11, 12 -C). 


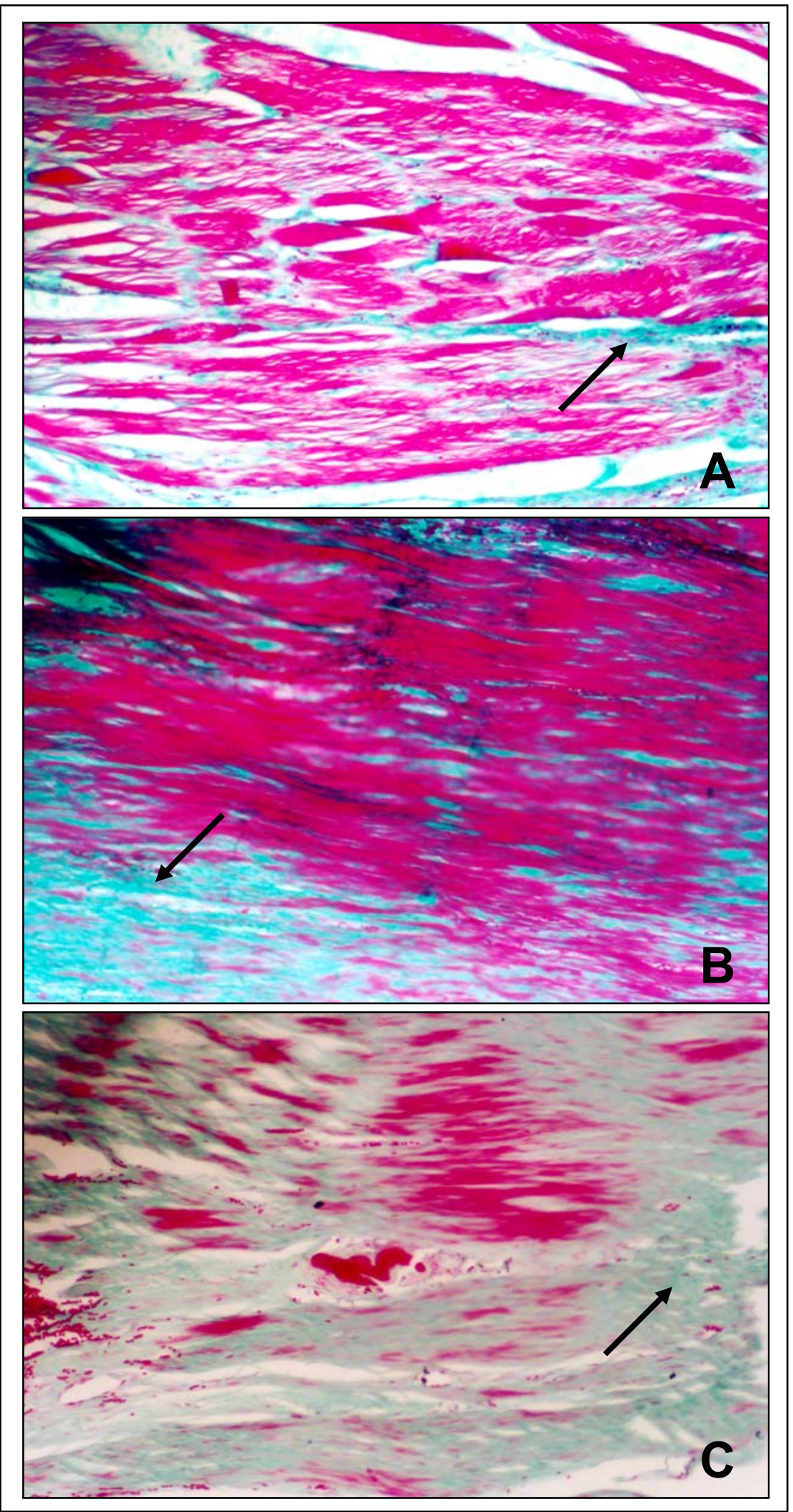

FIGURA 7 - Microscopia do tendão flexor: As setas demonstram na coloração azul-esverdeada a presença de aderência: Ilustração de um animal do grupo A (A); Ilustração de um animal do grupo B (B); Ilustração de um animal do grupo C (C). Mostrando maior presença de aderência no grupo C. Corados por Tricômio de Gomori. Corte longitudinal. Aumento de $100 \mathrm{x}$. 

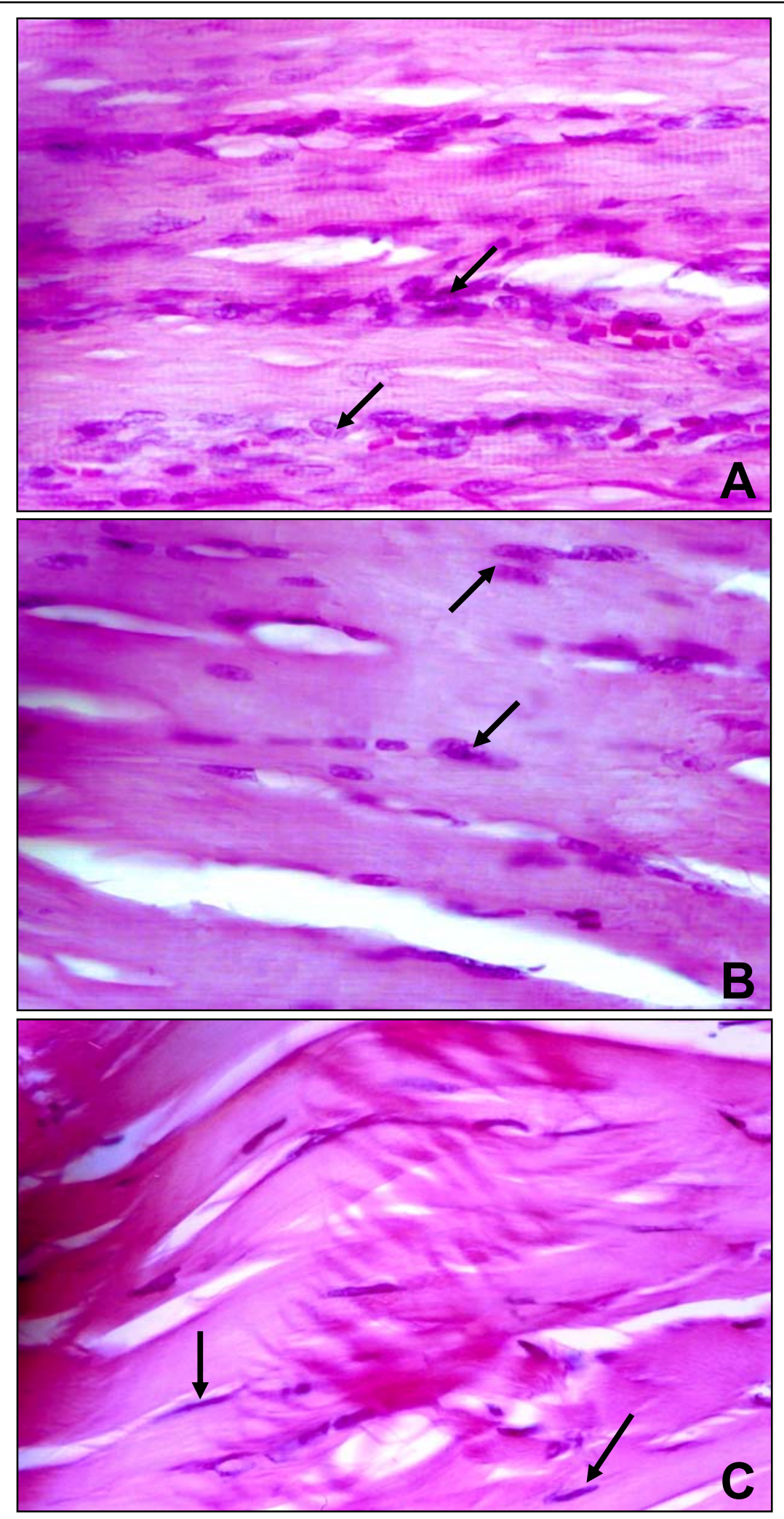

FIGURA 8 - Microscopia do tendão flexor: As setas demonstram a presença de estruturas alongadas, os fibroblastos: Ilustração de um animal do grupo A (A); Ilustração de um animal do grupo B (B); Ilustração de um animal do grupo C (C). Mostrando maior proliferação de fibroblastos no grupo A. Corados por Hematoxilina Harris/Eosina Floxina. Corte longitudinal. Aumento de 400x. 


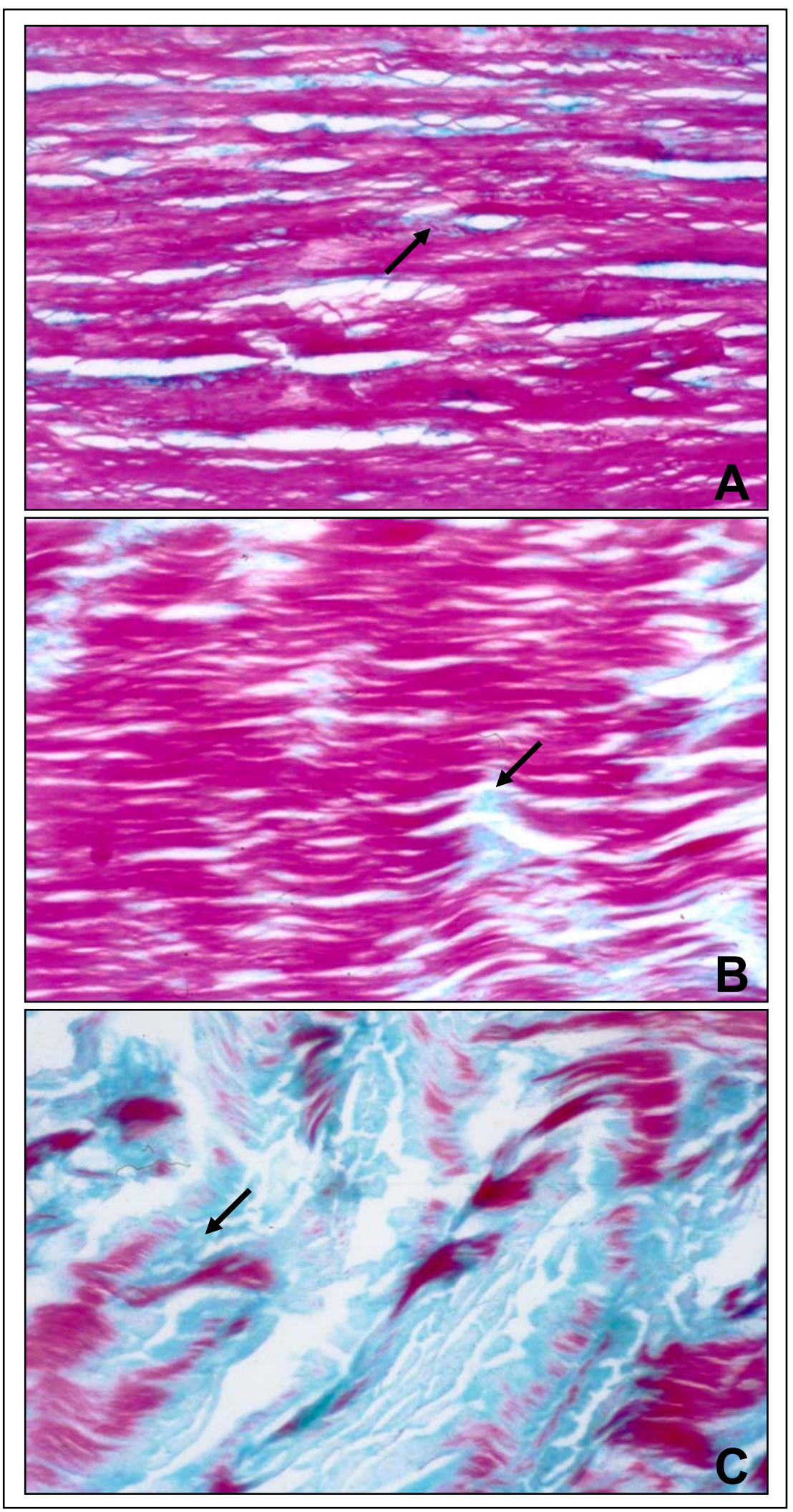

FIGURA 9 - Microscopia do tendão flexor: As setas demonstram na presença de colágeno: Ilustração de um animal do grupo A (A); Ilustração de um animal do grupo B (B); Ilustração de um animal do grupo $\mathrm{C}(\mathrm{C})$. Mostrando maior deposição de fibras de colágeno no grupo $\mathrm{C}$. Corados por Tricômio de Gomori. Corte longitudinal. Aumento de 100x. 


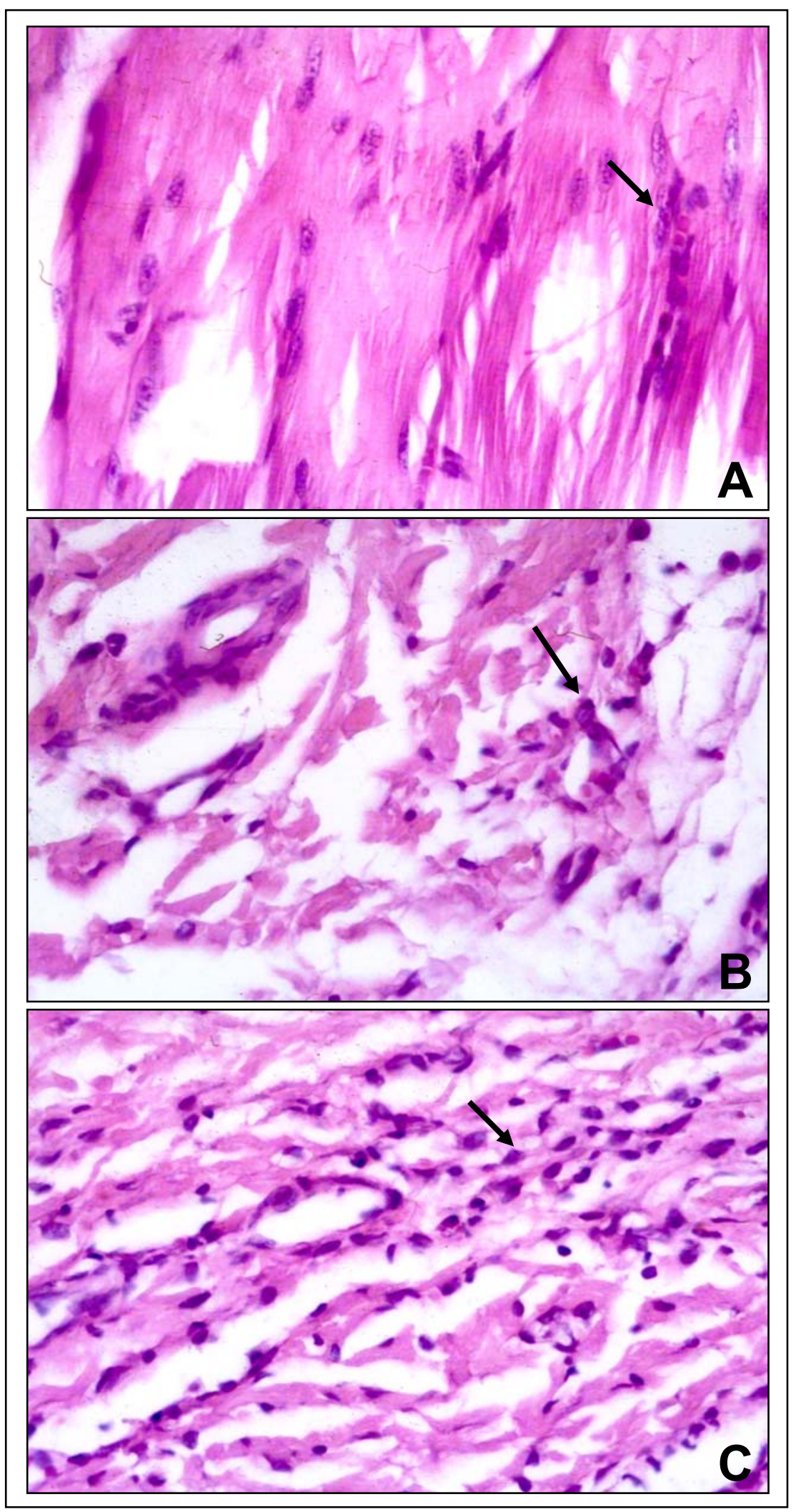

FIGURA 10 - Microscopia do tendão flexor: As setas demonstram a presença de células inflamatórias. Ilustração de: um animal do grupo A (A); um animal do grupo B (B); um animal do grupo C (C). Mostrando uma maior reação inflamatória no grupo A. Corados por Hematoxilina Harris/Eosina Floxina. Corte longitudinal para A e corte transversal para B e C. Aumento de 400x. 


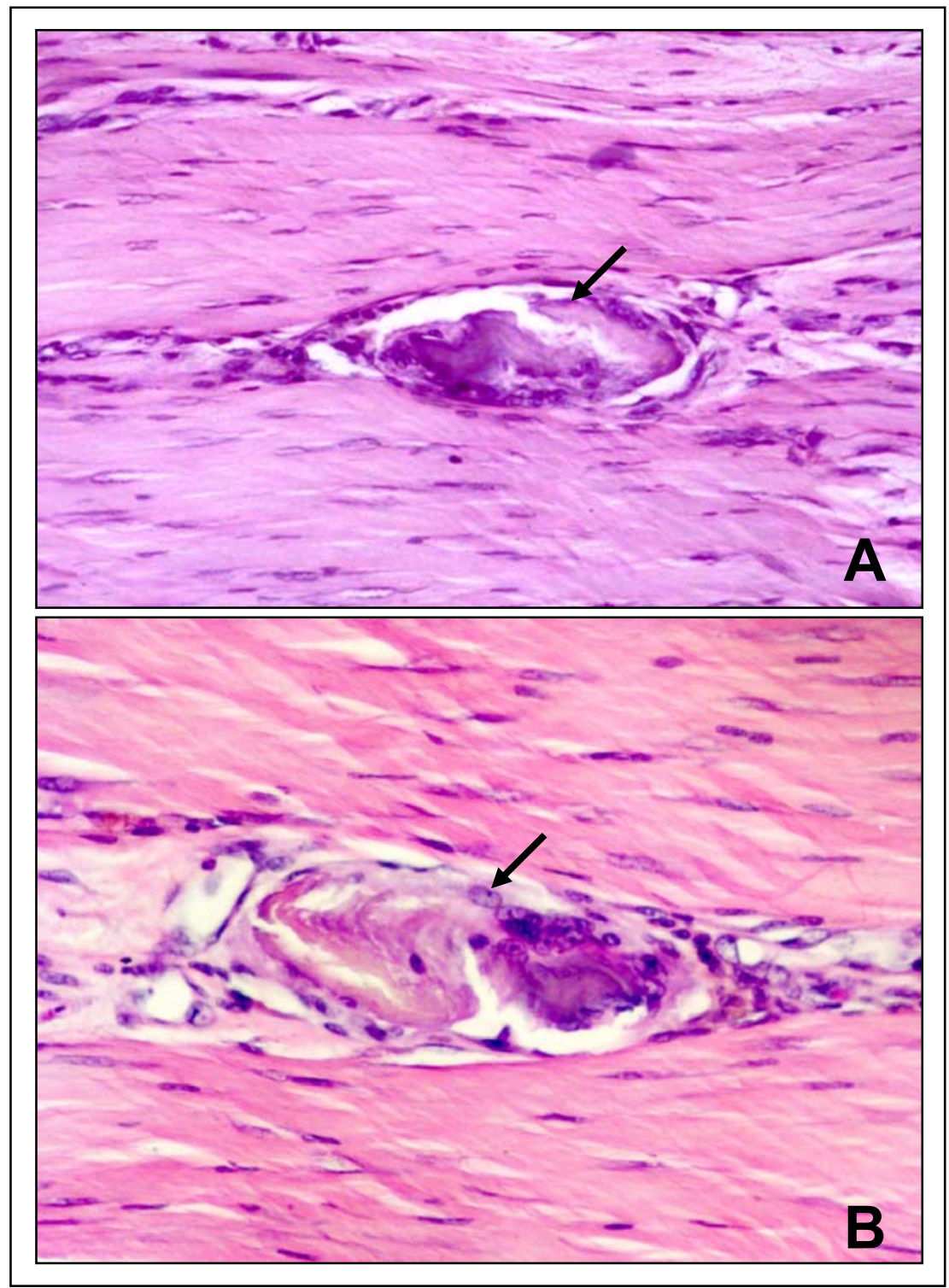

FIGURA 11 - Microscopia do tendão flexor: As setas demonstram a presença de microcalcificações: Ilustração de um animal do grupo A (A); Ilustração de uma animal do grupo B (B). Corados por Hematoxilina Harris/Eosina Floxina. Corte longitudinal. Aumento de 200x. 


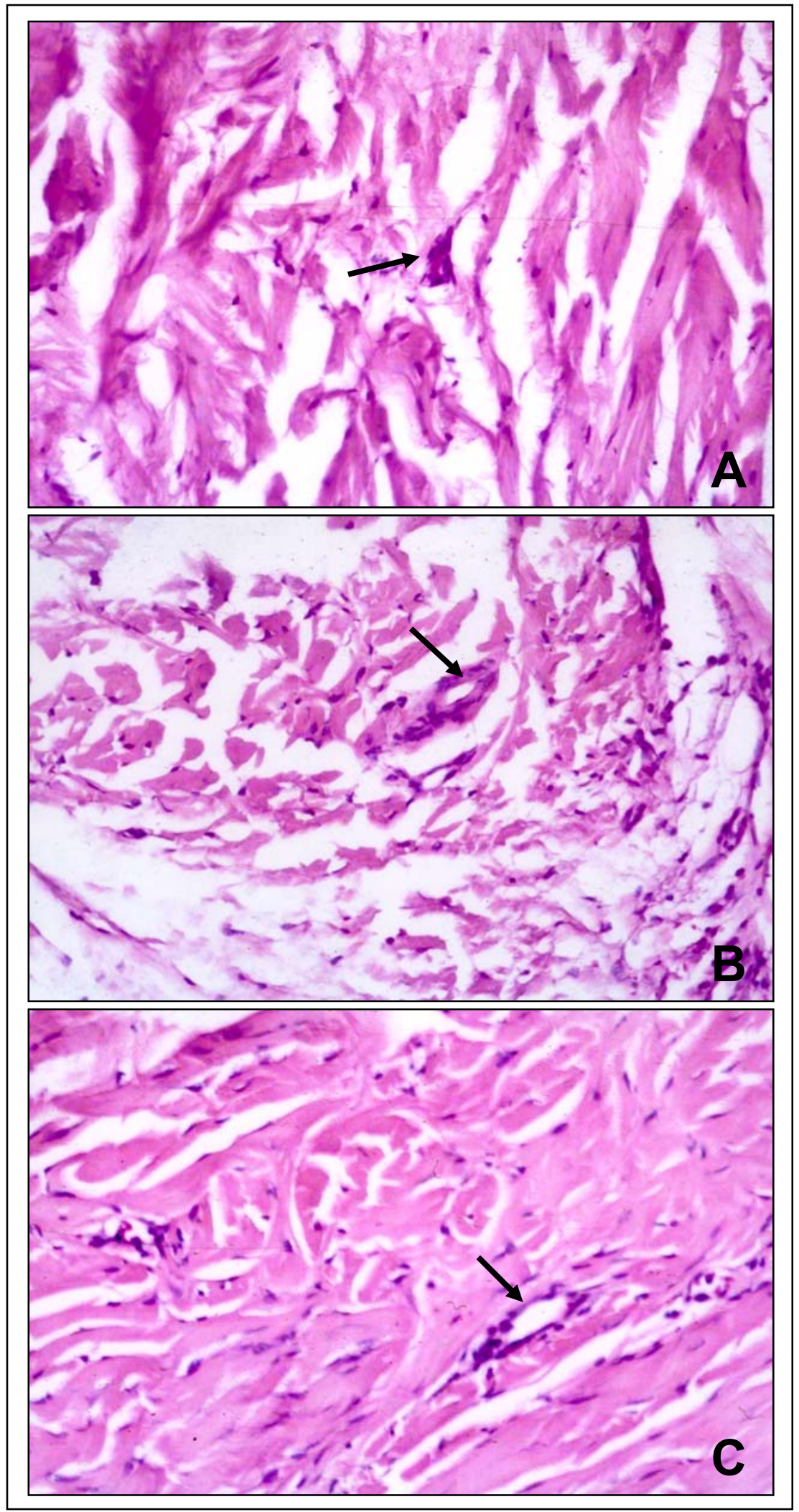

FIGURA 12 - Microscopia do tendão flexor: Vascularização - As setas demonstram a presença da luz de capilares: Ilustração de um animal do grupo A (A); Ilustração de um animal do grupo B (B): Ilustração de um animal do grupo C (C). Mostrando maior presença da variável no grupo C. Corados por Hematoxilina Harris/ Eosina Floxina. Corte transversal. Aumento de 200x. 


\subsection{Grupos A $\left(0,2 \mathrm{~W} / \mathrm{cm}^{2}\right)$ X Grupo B $\left(0,4 \mathrm{~W} / \mathrm{cm}^{2}\right)$}

\subsubsection{Variável aderência}

Não houve diferença estatisticamente significativa $(p=0.24)$ entre estes dois grupos. Em valores absolutos observou-se um grau maior de aderência tendinosa no grupo B.

\subsubsection{Variável proliferação de fibroblastos}

Houve diferença estatisticamente significantiva entre estes dois grupos $(\mathrm{p}=$ 0.03). Em valores absolutos, observou-se uma maior proliferação de fibroblastos no grupo A.

\subsubsection{Variável deposição de fibras de colágeno}

Não houve diferença estatisticamente significativa entre estes dois grupos $(\mathrm{p}=$ 0.86). Em valores absolutos observou-se um grau maior deposição de fibras de colágeno no grupo B.

\subsubsection{Variável células inflamatórias}

Não houve diferença estatisticamente significativa entre estes dois grupos $(p=$ 0.93). Em valores absolutos observa-se um grau maior de presença de células inflamatórias no grupo A. 


\subsubsection{Variável microcalcificações}

Não houve diferença estatisticamente significante entre estes dois grupos $(p=$ 0.99). Em valores absolutos observa-se graus iguais de presença de microcalcificações.

\subsubsection{Variável vascularização}

Não houve diferença estatisticamente significativa entre estes dois grupos $(p=$ 0.58). Em valores absolutos observa-se um grau maior de vascularização no grupo B.

\subsection{Grupo A $\left(0,2 \mathrm{~W} / \mathrm{cm}^{2}\right)$ X Grupo C (ultra-som desligado)}

\subsubsection{Variável aderência}

Houve diferença estatisticamente significativa entre estes dois grupos $(p=$ 0.04). Em valores absolutos observa-se grau maior de aderência no grupo C.

\subsubsection{Variável proliferação de fibroblastos}

Houve diferença estatisticamente significativa entre estes dois grupos $(\mathrm{p}=$ 0,002). Em valores absolutos observa-se uma maior proliferação de fibroblastos no grupo A.

\subsubsection{Variável deposição de fibras de colágeno}

Houve diferença estatisticamente significativa entre estes dois grupos $(p=$ 0,03). Em valores absolutos observou-se um grau maior deposição de fibras de colágeno no grupo $\mathrm{C}$. 


\subsubsection{Variável células inflamatórias}

Não houve diferença estatisticamente significativa entre estes dois grupos $(\mathrm{p}=$ 0,850). Em valores absolutos observa-se um grau maior de presença de células inflamatórias no grupo A.

\subsubsection{Variável microcalcificações}

Não houve diferença estatisticamente significativa entre estes dois grupos $(p=$ 0,32). Em valores absolutos observa-se um grau maior de microcalcificações no grupo A.

\subsubsection{Variável vascularização}

Houve diferença estatisticamente significativa entre estes dois grupos $(p=$ 0,02). Em valores absolutos observa-se um grau maior de vascularização no grupo C.

\subsection{Grupo B (0,4 W/cm²) X Grupo C (ultra-som desligado)}

\subsubsection{Variável aderência}

Não houve diferença estatisticamente significativa entre estes dois grupos ( $p=$ 0,10). Em valores absolutos observa-se um grau maior de aderência no grupo C.

\subsubsection{Variável proliferação de fibroblastos}

Não houve diferença estatisticamente significativa entre estes dois grupos $(\mathrm{p}=$ 0,17). Em valores absolutos observa-se uma maior proliferação de fibroblastos no grupo B. 


\subsubsection{Variável deposição de fibras de colágeno}

Houve diferença estatisticamente significativa entre estes dois grupos $(p=$ 0,07). Em valores absolutos observa-se um grau maior deposição de fibras de colágeno no grupo $\mathrm{C}$.

\subsubsection{Variável células inflamatórias}

Não houve diferença estatisticamente significativa entre estes dois grupos $(p=$ 0,88). Em valores absolutos observa-se um grau maior de células inflamatórias no grupo B.

\subsubsection{Variável microcalcificações}

Não houve diferença estatisticamente significativa entre estes dois grupos $(p=$ 0,32). Em valores absolutos observa-se um grau maior de microcalcificações no grupo B.

\subsubsection{Variável vascularização}

Houve diferença estatisticamente significativa entre estes dois grupos $(p=$ 0,08). Em valores absolutos observa-se um grau maior de vascularização no grupo C. 


\subsection{Resultados da demonstração gráfica dos 3 grupos}

\subsubsection{Aderência}

Os resultados da variável aderência estão demonstrados na TABELA 1. A FIGURA 13 demonstra o histograma ilustrando o comportamento das variáveis entre os grupos A, B e C.

TABELA 1 - Resultados da variável aderência.

\begin{tabular}{cccc}
\hline & Média & Dp & Mediana \\
\hline Grupo A & 1.40 & 1.27 & 1.0 \\
\hline Grupo B & 2.00 & 0.68 & 2.0 \\
\hline Grupo C & 2.50 & 0.71 & 3.0 \\
\hline
\end{tabular}

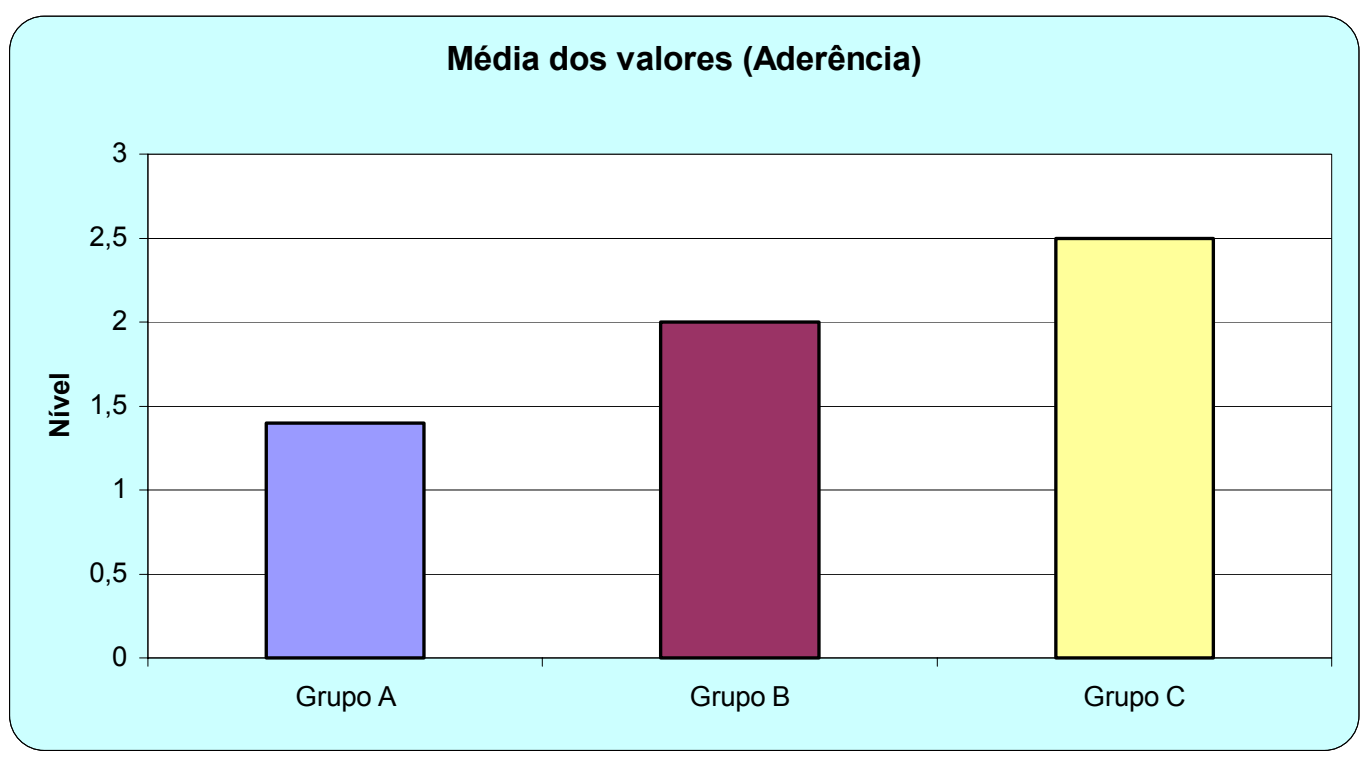

FIGURA 13 - Comparação dos valores da variável aderência - Histograma ilustrando o comportamento da variável entre os grupos A, B e C. 


\subsubsection{Proliferação de Fibroblastos}

Os resultados da variável proliferação de fibroblastos estão demonstrados na

TABELA 2. A FIGURA 14 demonstra o histograma ilustrando o comportamento das variáveis entre os grupos A, B e C.

TABELA 2 - Resultados da variável proliferação de fibroblastos.

\begin{tabular}{cccc} 
& Média & Dp & Mediana \\
\hline Grupo A & 2.10 & 0.57 & 2.00 \\
\hline Grupo B & 1.50 & 0.53 & 1.50 \\
\hline Grupo C & 1.20 & 0.42 & 1.00 \\
\hline
\end{tabular}

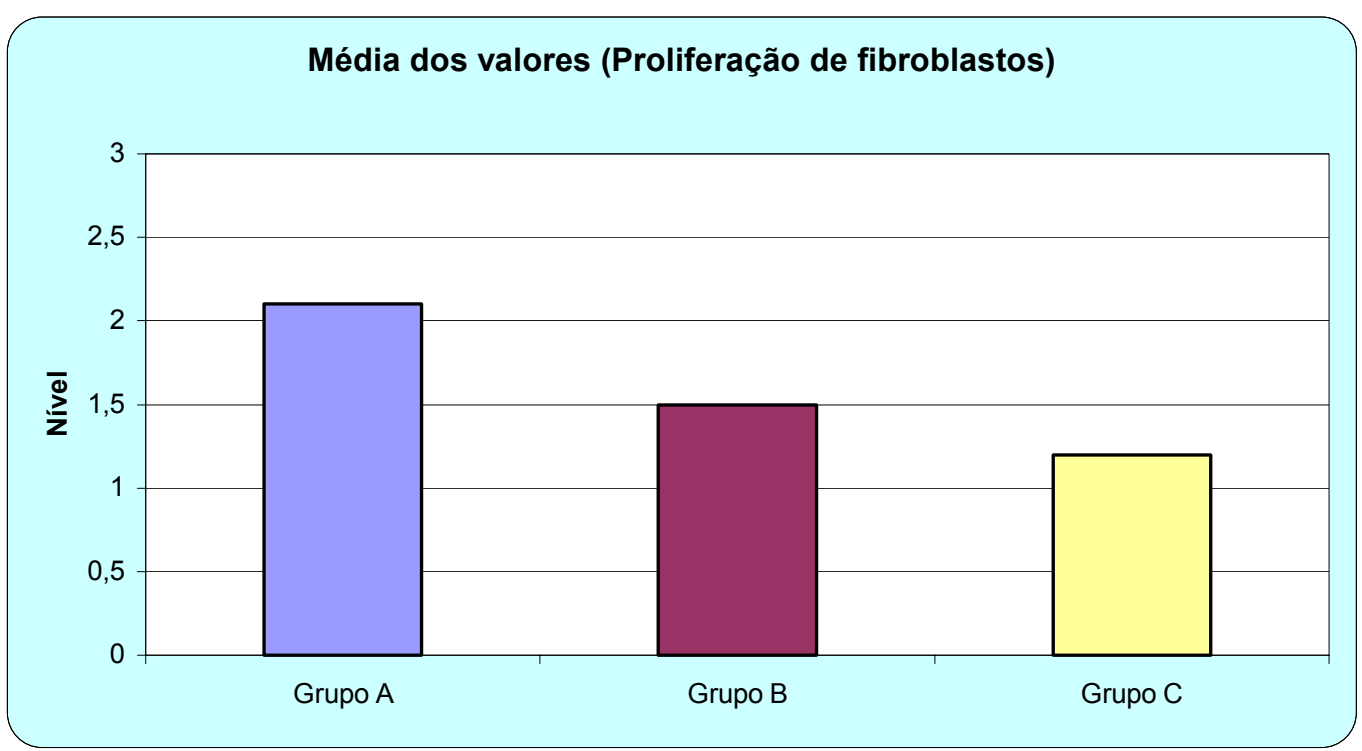

FIGURA 14 - Comparação dos valores da variável de fibroblastos - Histograma ilustrando o comportamento da variável entre os grupos A, B e C. 


\subsubsection{Deposição de Fibras de Colágeno}

Os resultados da variável deposição de fibras de colágeno estão demonstrados na TABELA 3. A FIGURA 15 demonstra o histograma ilustrando o comportamento das variáveis entre os grupos A, B e C.

TABELA 3 - Resultados da variável deposição de fibras de colágeno.

\begin{tabular}{cccc}
\hline & Média & Dp & Mediana \\
\hline Grupo A & 1.70 & 0.95 & 1.00 \\
\hline Grupo B & 1.80 & 1.03 & 1.00 \\
\hline Grupo C & 2.60 & 0.52 & 3.00 \\
\hline
\end{tabular}

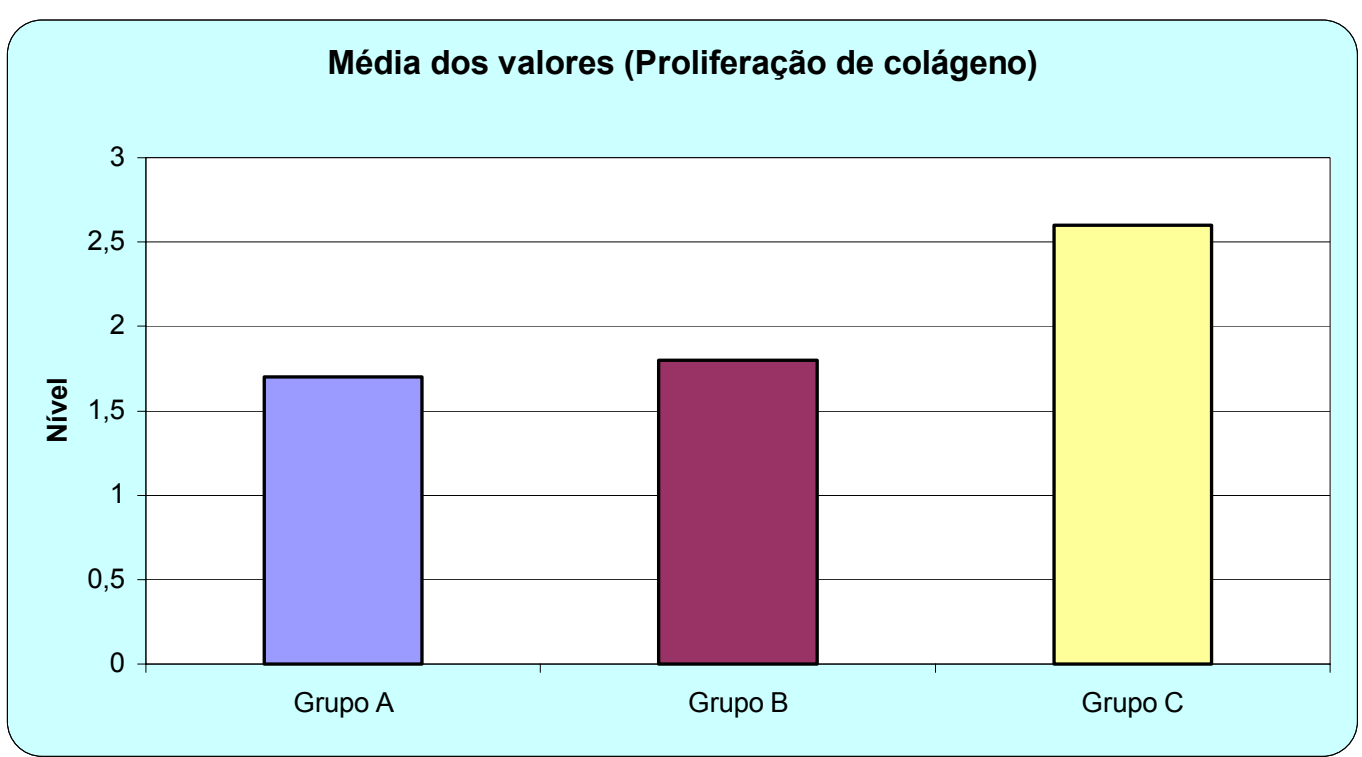

FIGURA 15 - Comparação dos valores da variável deposição de fibras de colágeno - Histograma ilustrando o comportamento da variável entre os grupos A, B e C. 


\subsubsection{Reação Inflamatória}

Os resultados da variável reação inflamatória estão demonstrados na

TABELA 4. A FIGURA 16 demonstra o histograma ilustrando o comportamento das variáveis entre os grupos $\mathrm{A}, \mathrm{B}$ e $\mathrm{C}$.

TABELA 4 - Resultados da variável reação inflamatória.

\begin{tabular}{cccc}
\hline & Média & Dp & Mediana \\
\hline Grupo A & 0.60 & 1.08 & 0.00 \\
\hline Grupo B & 0.50 & 0.85 & 0.00 \\
\hline Grupo C & 0.40 & 0.70 & 0.00 \\
\hline
\end{tabular}

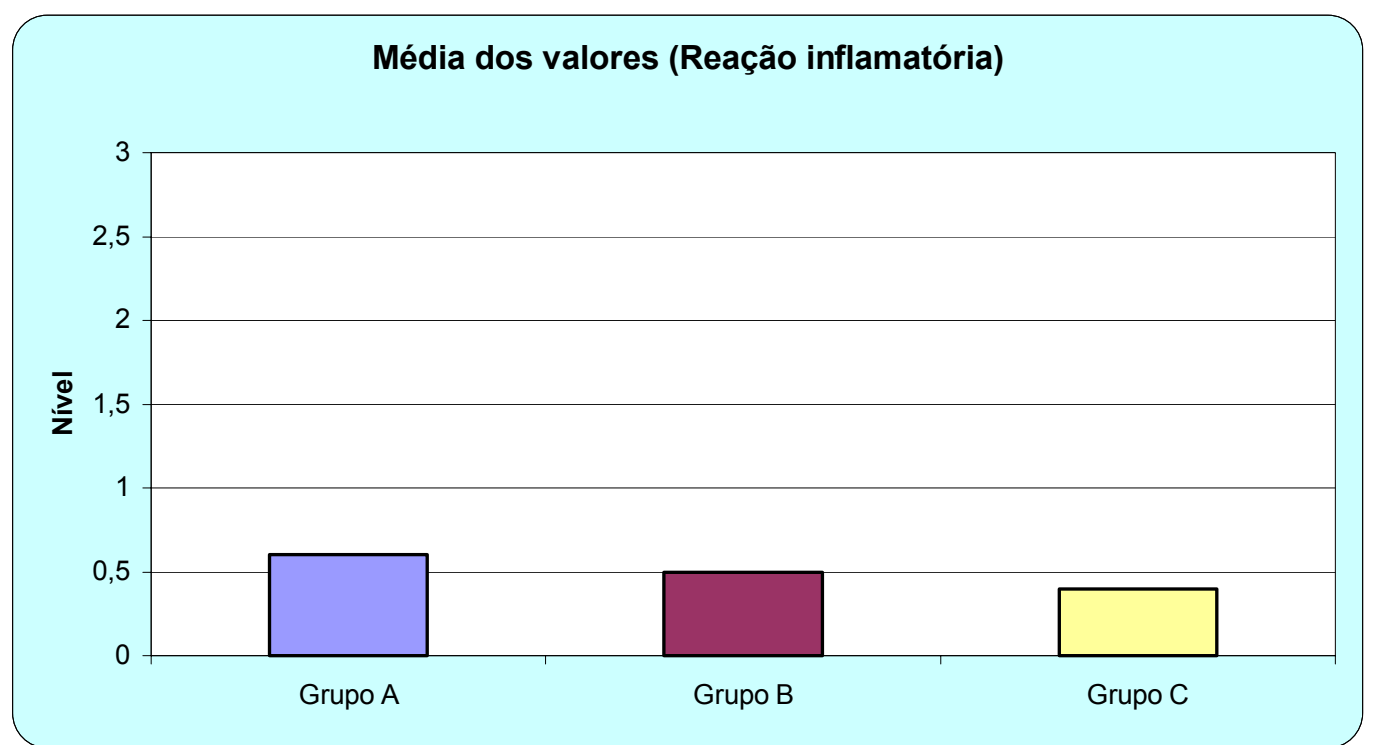

FIGURA 16 - Comparação dos valores da variável reação inflamatória - Histograma ilustrando o comportamento da variável entre os grupos A, B e C. 


\subsubsection{Microcalcificações}

Os resultados da variável presença de microcalcificações estão demonstrados na TABELA 5. A FIGURA 17 demonstra o histograma ilustrando o comportamento das variáveis entre os grupos A, B e C.

TABELA 5 - Resultados da variável microcalcificações.

\begin{tabular}{cccc} 
& Média & Dp & Mediana \\
\hline Grupo A & 0.10 & 0.32 & 0.00 \\
\hline Grupo B & 0.10 & 0.32 & 0.00 \\
\hline Grupo C & 0.00 & 0.00 & 0.00 \\
\hline
\end{tabular}

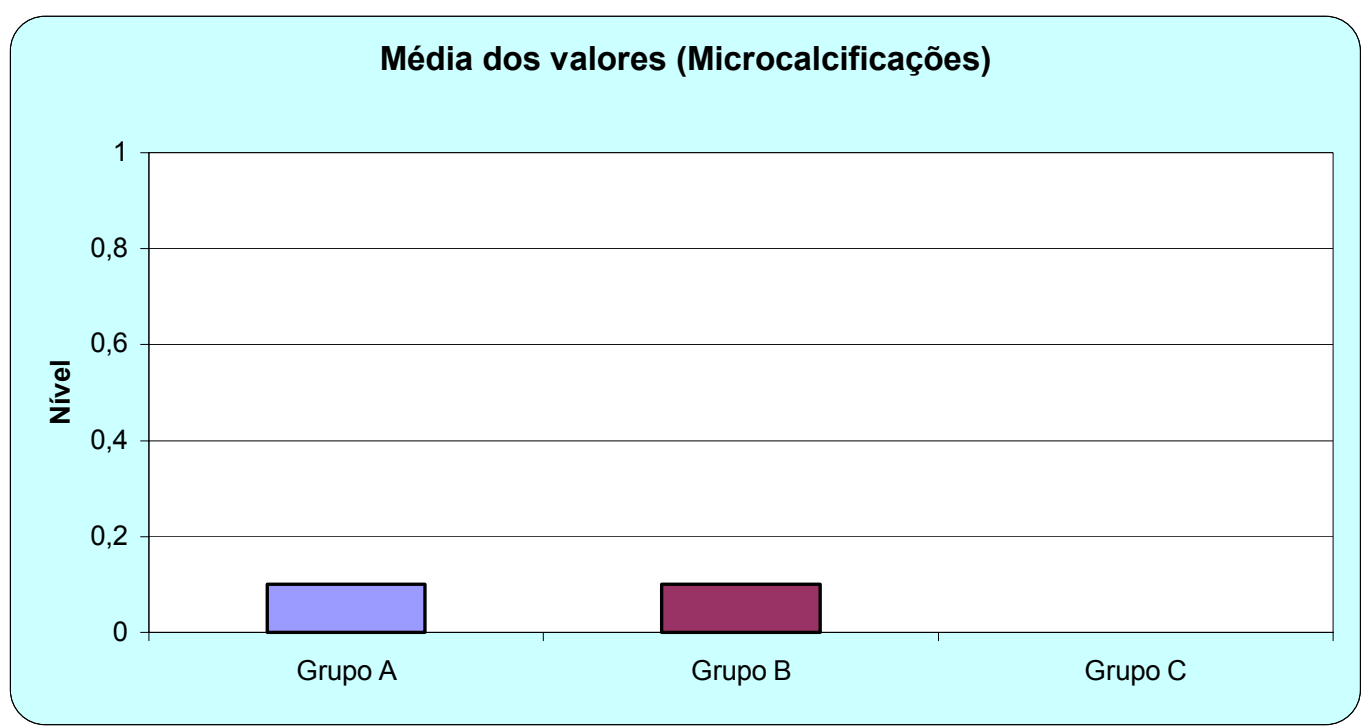

FIGURA 17 - Comparações dos valores da variável microcalcificação - Histograma ilustrando o comportamento da variável entre os grupos A, B e C. 


\subsubsection{Vascularização}

Os resultados da variável vascularização estão demonstrados na TABELA 6.

A FIGURA 18 demonstra o histograma ilustrando o comportamento das variáveis entre os grupos A, B e C.

TABELA 6 - Resultados da variável vascularização.

\begin{tabular}{cccc} 
& Média & Dp & Mediana \\
\hline Grupo A & 0.30 & 0.68 & 0.00 \\
\hline Grupo B & 0.50 & 0.85 & 0.00 \\
\hline Grupo C & 1.10 & 0.74 & 1.00 \\
\hline
\end{tabular}

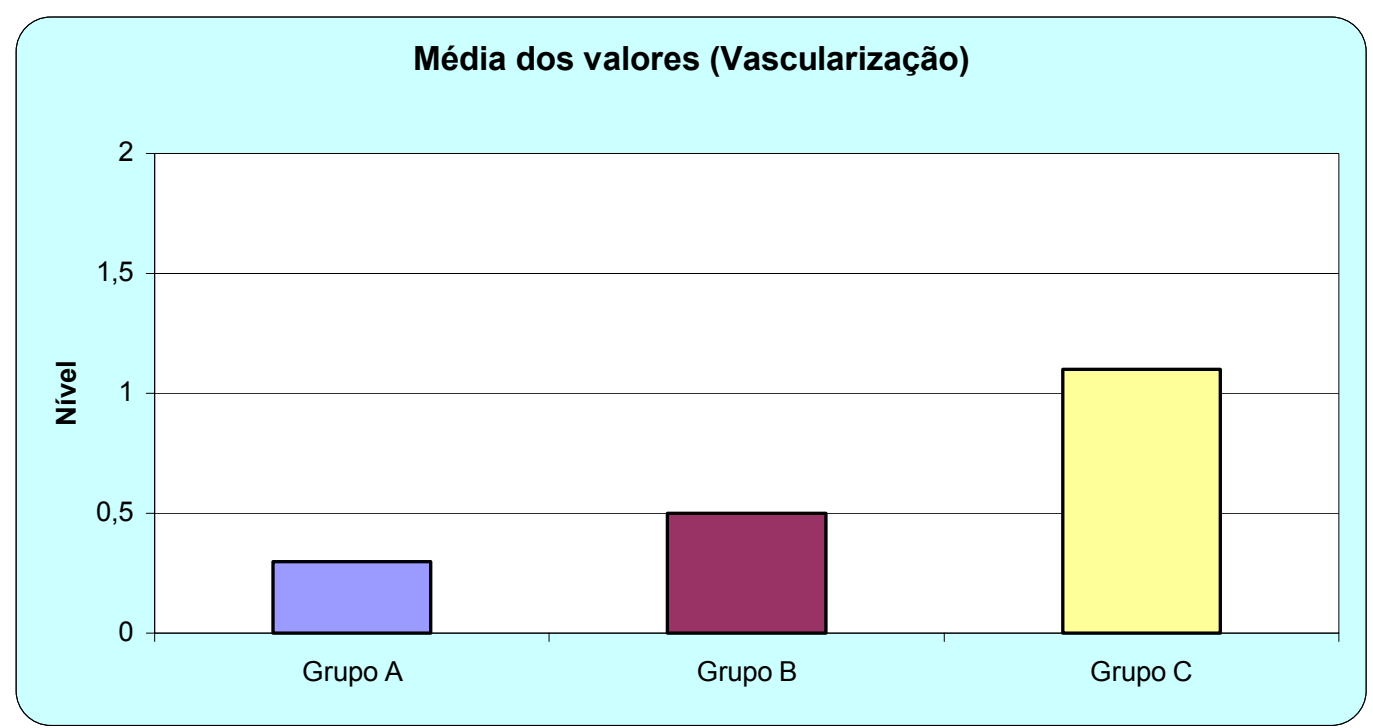

FIGURA 18 - Comparação dos valores da variável vascularização entre os grupos A, B e C. 


\section{DISCUSSÃO}

Sobania (1992) relatou que um dos maiores problemas da cirurgia restauradora dos tendões flexores é evitar a formação de aderências, que provocam maus resultados, pois nos tendões, tanto a cicatrização como o deslizamento são igualmente importantes.

No processo de regeneração do tendão, os fibroblastos são solicitados por causa da lesão e se multiplicam sintetizando colágeno e os polissacarídes da substância fundamental amorfa (JUNQUEIRA; CARNEIRO, 1999) que com o passar do tempo vão se organizando e se posicionando ao longo do eixo maior do tendão no processo de reparo da lesão, e quanto mais abundante é o tecido cicatricial formado pelos fibroblastos, maior será a formação de aderência desse tecido cicatricial aos tecidos adjacentes.

As propriedades viscoelásticas proporcionam uma capacidade de deslizamento aos tendões, para que os mesmos funcionem adequadamente com o mínimo de atrito. Esta capacidade pode estar deficiente ou perdida quando ocorrem traumatismos ou intervenções cirúrgicas, sendo uma das complicações mais freqüentes a formação de aderências cicatriciais, provocadas também pelo efeito da imobilização, resultando em um leito de má qualidade, e em muitos casos, necessitando de reoperações para retirada dessas aderências.

Segundo Fukui et al. (2001) várias pesquisas para reduzir a formação de aderências têm sido feitas utilizando materiais biológicos e sintéticos (enxerto de 
vaso, polietileno, lâmina de Silastic) e agentes bioquímicos (esteróides, agentes antiinflamatórios não-esteróides, ácido hialurônico). Poucos produtos empregados nestes estudos são comumente utilizados.

Por esta razão resolvemos estudar a possível ação benéfica e precoce da aplicação do ultra-som na prevenção da formação de aderências tendinosas.

O ultra-som foi utilizado durante anos na prática clínica, para o tratamento das lesões dos tecidos moles (DYSON, 1987; YOUNG; DYSON, 1990). Ele é indicado tanto para o tratamento em condições agudas como crônicas (KITCHEN; PARTRIDGE, 1990), podendo afetar os tecidos de várias maneiras, dependendo do estágio da lesão e dos parâmetros utilizados (McDIARMID et al., 1985).

No início o ultra-som foi empregado de modo contínuo para o tratamento dos processos inflamatórios, liberação de aderências e cicatrização de tecidos. O modo pulsado foi introduzido no ano de 1960, com o objetivo de diminuir a possibilidade de lesões teciduais provocadas pelos efeitos térmicos.

Muitos estudos investigaram os efeitos fisiológicos do ultra-som na cicatrização tendinosa (ROBERTS; RUTHERFORD; HARRIS, 1982; STEVENSON et al., 1986; TURNER; POWELL, 1989; ENWEMEKA, 1989; JACKSON; SCHWANE; STARCHER, 1991; GAN et al. 1995; BARROS JR, 2001; ROMANO, 2001), mas estudos para as complicações da cicatrização como a formação de aderências foram apenas citados nos trabalhos sobre a cicatrização de tecidos moles.

Nossos resultados poderão então, auxiliar na evolução do conhecimento do ultra-som como recurso terapêutico na prevenção das aderências tendinosas. 
O tendão flexor profundo do $3^{\circ}$ dedo na transição entre as zonas 3 e 4 foi escolhido pela facilidade de acesso, do procedimento cirúrgico que não requer treinamento especial e reparo cirúrgico e pela fácil identificação do tendão.

Uma lesão no tendão pode ser resultado de trauma direto, perfurante, sem corte, por esmagamento ou avulsão do tendão, entre outras. As lesões por esmagamento são de maior gravidade e resultam na maioria das vezes de trauma em prensas. Rothkopf et al. (1991) elegeram a escarificação associada ao esmagamento, por um período de 10 minutos como modelo experimental traumático seus estudos. Este modelo foi utilizado em nosso trabalho, onde foi observado o aspecto avascular do tendão após o procedimento. A carga de $15 \mathrm{~kg}$ foi estipulada na observação macroscópica de completo esmagamento do tendão, e foi possível padronizar a intensidade de lesão produzida. Esta mesma carga foi utilizada em outros trabalhos onde foi realizado o esmagamento em nervos (MENDONÇA, 2000).

A escolha de coelho como animal de experimentação deveu-se ao fato da facilidade de manuseio e da execução dos procedimentos, por ser um tendão sinovial, e também por apresentarem resultados satisfatórios em outros estudos (ENWEMEKA, 1989b; ENWEMEKA; RODRIGUEZ; MENDONSA, 1990; GAN et al. 1995; JACKSON; SCHWANE; STARCHER, 1991; STEVENSON, 1986).

O equipamento de ultra-som foi previamente calibrado, a dosimetria foi realizada antes da aplicação e também no decorrer do trabalho, realizada através da medida da energia emitida na área reduzida do transdutor.

Por apresentar um coeficiente de absorção maior nos tecidos (HOOGLAND, 1986) e ser utilizado freqüentemente na prática clínica em humanos, a freqüência de $3 \mathrm{MHz}$ foi selecionada para o estudo. 
A escolha do modo contínuo baseou-se nos efeitos térmicos de aquecimento, que produz um aumento temporário da extensibilidade de estruturas altamente colagenosas e na diminuição de rigidez (DYSON, 1987).

A intensidade de 0,2 e $0,4 \mathrm{~W} / \mathrm{cm}^{2}$ foram selecionadas por freqüentemente serem utilizadas na prática clínica.

Foi optado pelo $21^{\circ}$ pós-operatório para analisar o processo de aderência, pois neste período a formação de aderências é evidenciada, e também para avaliar o efeito precoce e a rápida recuperação do tendão.

Após 3 dias da produção da lesão, período em que ocorre a diminuição da reação inflamatória, iniciou-se a aplicação do ultra-som, sendo o tratamento iniciado ainda na fase aguda, por 7 dias consecutivos. Após o término dos 7 dias de aplicação do ultra-som aguardamos até o $21^{\circ}$ de pós-operatório para o sacrifício do animal para que ocorresse a formação de aderências.

O tempo de aplicação escolhido foi de 5 minutos por ser usado na prática clínica (DYSON, 1987) e por ser suficiente para gerar os efeitos térmicos e atérmicos (DYSON, et al., 1968) em áreas pequenas, como a pata de coelho.

A aplicação por contato direto permitiu o completo acoplamento entre o transdutor e a região a ser sonada, e foi necessário usar um cabeçote com área reduzida. Foi usado o gel como agente acoplador evitando a reflexão na interface ar/tecido (McDIARMID; BURNS, 1987), realizando movimentos longitudinais.

A órtese de imobilização em flexão foi empregada no pós-operatório por 21 dias para promover a cicatrização do tendão e estimular a formação de aderências, evitando a influência dos movimentos. A imobilização da pata operada foi 
empregada rotineiramente em outros trabalhos experimentais (POTENZA, 1962; BARROS JR, 2001; ROMANO, 2001).

A análise semi-quantitativa foi empregada por Rothkopf et al. (1991), por Barros Jr (2001) e também por ser bem aceita entre os patologistas.

Os resultados da histo-morfologia para a variável formação de aderência, demonstrou diferenças estatisticamente significantes, sendo que o grupo C apresentou valores significativamente maiores que o grupo A, e o grupo B permaneceu em uma posição intermediária, nem significativamente maior que A nem significativamente inferior ao grupo $\mathrm{C}$, sugerindo que o ultra-som para prevenção de aderências deve ser empregado com uma intensidade mais baixa.

Os mesmos resultados foram obtidos por Romano (2001) utilizando o mesmo modelo, mas com outra metodologia e outra dose.

Para a variável presença de fibroblastos, houve diferenças estatisticamente significantes, com valores maiores para o grupo A, o grupo B com valores intermediários e valores menores para o grupo $\mathrm{C}$, sugerindo que o ultra-som terapêutico influenciou na proliferação de fibroblastos.

Nos trabalhos de Harvey et al., ${ }^{1}$ apud Dyson (1987) os fibroblastos quando expostos a ultra-som, seriam estimulados a sintetizar um maior número de colágeno, resultando em um tecido mais resistente, o que possibilita na fase de remodelação um tecido cicatricial mais forte e elástico.

Em seu estudo, Enwemeka (1989b) relatou que a proliferação e a síntese protéica podem ser facilitados pelo uso do ultra-som terapêutico.

${ }^{1}$ HARVEY, W; DYSON, M; POND, J; GRAHAME, R. The in vitro stimulation of protein synthesis in human fibroblasts by therapeutic levels of ultrasound. Proceedings of the Second European Congress on Ultrasonics in Medicine, Excepta Medica, Amsterdan, p.10-21, 1975. 
Por outro lado, Barros Jr (2001) em seu estudo não observou a interferência do ultra-som na fase inicial da cicatrização em tendões de coelhos.

Em nossos achados quanto a deposição de fibras de colágeno, observamos que houve diferenças estatísticas, com valores menores para o grupo A e B e valores maiores para o grupo $\mathrm{C}$, indicando que a terapia por ultra-som diminuiu a síntese de colágeno.

Stevenson et al. (1986) em seus estudos, não observaram uma diminuição da síntese de colágeno.

Este resultado também foi encontrado por Barros Jr (2001), na fase precoce da cicatrização utilizando o ultra-som, aplicado em tendões flexores de coelhos.

Em nossos achados observamos uma aceleração da resolução da resposta inflamatória nos 3 grupos, não havendo diferenças estatísticamente significativas.

Dyson (1987) relatou que o ultra-som não deve ser considerado como um agente anti-inflamatório, apesar de ter observado que este acelerou a resolução da resposta inflamatória.

Para a variável microcalcificações, estatisticamente não houve diferenças significantes, com valores iguais para os 3 grupos, consideramos a presença devido ao trauma no tendão e à imobilização. Não encontramos na literatura resultados semelhantes para comparações.

Para a variável vascularização, estatisticamente houve diferenças significativas, com valores iguais para os grupos A e B e valores maiores para o grupo C, sugerindo que o ultra-som não influenciou na rede vascular.

Segundo Barros Jr (2001) para que se atinja um efeito eficiente do ultra-som, tem que se determinar o tempo e a dose, conhecer os mecanismos da formação de 
aderências, da deposição de colágeno maduro e a recuperação funcional dos tendões reparados.

Concluímos, que os resultados deste trabalho demonstraram que a irradiação ultra-sônica na freqüência de $3 \mathrm{MHz}$, com a intensidade de $0,2 \mathrm{~W} / \mathrm{cm}^{2}$, no modo contínuo, em aplicações diárias durante 5 minutos, por 7 dias consecutivos, iniciados no $3^{\circ}$ dia de pós-operatório, em tendões submetidos à esmagamento, promoveu uma menor formação de aderências em comparação com a intensidade de $0,4 \mathrm{~W} / \mathrm{cm}^{2}$, e uma formação maior para o grupo controle, com aceleração do reparo tendinoso em todos os grupos.

Estudos posteriores se faz necessário, com a utilização da variação nos parâmetros físicos do ultra-som terapêutico e do período de tratamento, objetivando a determinação da efetividade do ultra-som sobre a formação de aderências e no reparo tendinoso. 


\section{CONCLUSÃO}

Os resultados deste presente estudo sugerem:

1. que a aplicação precoce do ultra-som terapêutico com os parâmetros empregados (freqüência de $3 \mathrm{MHz}$, intensidade de $0.2 \mathrm{~W} / \mathrm{cm}^{2}$, modo contínuo, duração de 5 minutos) mostrou-se efetivo para uma menor formação de aderências tendinosas;

2. a evidência de uma melhora no reparo tecidual após lesão experimental por esmagamento do tendão de coelhos, produzidas pela aplicação de uma carga de $15 \mathrm{Kg}$ por 10 minutos, conforme observados pela análise morfológica. 


\section{REFERÊNCIAS BIBLIOGRÁFICAS}

BARNETT, S.B.; Ter HAAR, G.R.; ZISKIN, M.C.; NYBORG, W.L.; MAEDA, K.; BANG, J. Current status of research on biophysical effects of ultrasound. Ultrasound in Medicine and Biology, Oxford, v.20, n.3, p.105-18, Dec., 1994.

BARROS JR, E.A. Os efeitos do ultra-som na cicatrização de tendões flexores de coelhos após tenorrafia.. 2001. 57p. Dissertação (Mestrado) - Escola de Engenharia de São Carlos / Faculdade de Medicina de Ribeirão Preto, Universidade de São Paulo, Ribeirão Preto, 2001.

BUNNELL, S. Surgery of the hand. $3^{\text {nd }}$, London: Lippincott Company, 1956, 1079 p.

COAKLEY, W.T. Biophysical effects of ultrasound at therapeutic intensities. Physiotherapy, London, v.62, n. 6, p.166-9, Jun., 1978.

CUNHA, A.; PARIZOTTO, N.V.; VIDAL, B.C. The effects of ultrasound on repair of the Achilles tendon (tendo calcaneus) of the rat. Ultrasound in Medicine and Biology, Oxford, v. 27, n. 12, p. 1691-96, Dec., 2001.

DEFINO, H.L.A.; BARBIERI, C.H.; MORAES, J.R.E.; VUGMAN, I. Presença de cartilagem em tendões flexores. Revista Brasileira de Ortopedia, Rio de Janeiro, $\mathrm{v}$ 23, n. 6, p. 157-62, jun, 1988.

DIONÍSIO, V.C. O efeito do ultra-som terapêutico na vascularização pós lesão muscular experimental em coelhos. . 1998. 51p. Dissertação (Mestrado) - Escola de engenharia de São Carlos / Faculdade de Medicina de Ribeirão Preto, Universidade de São Paulo, Ribeirão Preto, 1998.

DOCKER, M.F. A review of instrumentation available for therapeutic ultrasound. Physiotherapy, London, v. 73, n. 4, p. 154-55, Apr., 1987.

DOCKER, M.F.; PATRICK, M.K.; FOULKES, D.J. Ultrasound complaints for physiotherapy. Physiotherapy, London, v. 68, n. 4, p. 124-25, Apr., 1982.

DUARTE, L.R.; XAVIER, C.A.M. Estimulação ultra-sônica do calo ósseo. Revista Brasileira de Ortopedia, Rio de Janeiro, v.18, n. 3, p. 73-80, mai.-jun., 1983.

DYSON, M. Mechanisms involved in therapeutic ultrasound. Physiotherapy, London, v. 73, n. 3, p. 116-20, Mar., 1987.

DYSON, M. Non-thermal cellular effects of ultrasound. British Journal of Cancer, London, v. 45, n. 5, p. 165-71, Mar., 1982. 
DYSON, M.; POND, J.B.; JOSEPH, J.; WARWICK, R. The stimulation of tissue regeneration by means of ultrasound. Clinical Science, London , v. 35, n. 2, p. 27385, Apr., 1968.

DYSON, M.; SUCKLING, J. Stimulation of tissue repair by ultrasound: a survey of the mechanisms involved. Physiotherapy, London, v. 64, n. 4, p. 105-08, Apr., 1978.

ELLIS, H. The aetiology of post-operative abdominal adhesions. British Journal of Surgery, London, v. 50, n. 219, p. 10-16, 1962.

ENWEMEKA, C.S. Inflammation, cellularity and fibrillogenesis in regenerating tendon: Implications for tendon rehabilitation. Physical Therapy, Albany, v. 69, n. 10, p. 816-25, Oct, 1989a.

ENWEMEKA, C.S.; RODRIGUEZ, A; MENDOSA, S. The biomechanical effects of low-intensity ultrasound on healing tendons. Ultrasound in Medicine and Biology, Oxford, v. 16, n. 8, p. 801-07, 1990.

ENWEMEKA, C.S. The effects of therapeutic ultrasound on tendon healing: a biomechanical study. American Journal of Physical Medicine \& Rehabilitation, Baltimore, v. 68, n. 6, p. 283-87, Dec, 1989b.

FUIRINI JR, N.; LONGO, G.J. Ultra-Som. Amparo-SP/Relatório técnico KLDBiosistemas equipamentos eletrônicos LTDA, 1996.

FUKUI, N.; FUKUDA, A.; KOJIMA, K.; NAKAJIMA, K.; ODA, H; NAKAMURA, K. Suppression of fibrous adhesion by preteoglycan decorin. Journal of Orthopaedic Research, New York, v. 19, n. 3, p. 456-62, Mai., 2001.

FUKUI, N. ; TOSHIYUKI. T.; HIRAOKA, H.; ODA, H.; NAKAMURA, K. Adhesion formation can be reduced by the suppression of transforming growth factor-beta 1 activity, Journal of Orthopaedic Research, New York, v. 18, n. 2, p. 212-19, Mai., 2000.

GAN, B.S.; HUYS, S.; SHEREBRIN, M.H.; SCILLEY, C.G. The effects of ultrasound treatment on flexor tendon healing in the chicken limb. Journal of Hand Surgery, St. Louis, v. 20B, n. 6, p. 809-14, Dec., 1995.

GARAVELlO, I.; MAZZER, N.; BARBIERI, C.H.; ANDRADE, J.M. Efeitos térmicos do ultra-som terapêutico sobre os tecidos ósseo e muscular e sobre a placa metálica implantada. Revista Brasileira de Ortopedia, Rio de Janeiro, v. 32, n. 6, p. 473-79, jun., 1997.

GIGANTE, A.; SPECCHIA, N.; RAPALI, S.; VENTURA, A.; DE PALMA, L.Fibrilogenesis in tendon healing: an experimental study. Bollettino della Societá Italiana di Biologia Sperimentale, Napoli, v. 72, n. 7-8, p. 203-10, Jul./Aug., 1996.

GUM S.L.; REDDY, G.K.; STEHNO-BITTEL, L.; ENWEMEKA, C.S. Combined ultrasound, electrical stimulation, and laser promote collagen syntheses with 
moderate changes in tendon biomechanics. American Journal of Physical Medicine \& Rehabilitation, Baltimore, v. 76, n. 4, p. 288-96, Jul./Aug, 1997.

HATANO, I.; SUGA, T.; DIAO, E.; PEIMER, C.A.; HOWARD, C. Adhesions from flexor tendon surgery: an animal study comparing surgical techniques. The Journal of Hand Surgery, St. Louis, v. 25, n. 2, p.252-59, Mar., 2000.

HOGAN, R.D.; BURKE, K.M.; FRANKLIN, T.D. The effect of ultrasound on micro vascular hemodynamics in skeletal muscle: effects during ischemia. Microvascular Research, New York, v. 23, n. 3, p. 370-79, 1982.

HOOGLAND, R. Ultrasound Therapy. $2^{\text {nd }}$, B.V. Enraf-Nonius Delf, 1989.

JACKSON, B.A.; SCHWANE, J.A.; STARCHER, B.C. Effects of ultrasound therapy on the repair of Achilles tendon injuries in rats. Medicine and Science in Sports and Exercise, Madison, v. 23, n. 2, p. 171-76, Fev., 1991.

JUNQUEIRA, L.C.; CARNEIRO, J. Tecido Conjuntivo. In: JUNQUEIRA, L.C.; CARNEIRO, J. Histologia Básica. Rio de Janeiro: Guanabara Koogan, 1999, Cap. $5, \mathrm{p} 72-97$.

KANG, H.J.; PARK, B.M.; HAHN, S.B.; KANG, E.S. An experimental study of healing of the partially severed flexor tendon in chickens. Yonsey Medicine Journal, Seoul, v.31, n. 3, p. 264-73, Sep., 1990.

KESSLER, I.; NISSIN, F. Primary repair without immobilization of flexor tendon division within the digital sheath. Acta Orthopedica Scandinavica, Copenhagen, v. 40, n. 5, p. 587-601, 1969.

KITCHEN, S.S.; PARTRIDGE, C.J. The efficacy of ultrasound. Physiotherapy, London, v. 76, n. 10, p.595-8, Oct., 1990.

KLEINERT, H.E.; SCHEPEL, S.; GILL, T. Flexor tendons injuries. The Surgical Clinics of North America, Philadelphia, v. 61, n.2, p. 267-86, Apr., 1981.

KREMKAU, F.W. Physical considerations. In: NYBORG, L.N.; ZISKIN, M.C. Biological effects of ultrasound. New York: Churchill Livingstone, 1985, Cap. 2, p. 9-21.

LEHMANN J.F.; GUY, A.W. Interaction of ultrasound and biological tissues. In: REID, J.; SIKOV, M. Ultrasound therapy. Washington: DREW Publication, 1972, p. 141-52.

LEHMANN, J.F.; HERRIK, J.F. Biologic reations to cavitation a consideration for ultrasound therapy. Archives of Physical Medicine \& Rehabilitation, Chicago, v. 34, n. 3, p. 86-98, Jan., 1953.

LUNDBORG, G.; HOLM, S.; MYRHAGE, R. The role of the synovial fluid and tendon sheath for flexor tendon nutrition: An experimental tracer study on diffusional 
pathways in dogs. Scandinavian Journal of Plastic Reconstructive Surgery, Stockholm, v. 14, n. 1, p. 99-107, 1980.

MATTAR JR, R. Lesões traumáticas dos tendões flexores dos dedos e polegar. Apostila do I Curso sobre Traumatologia do Punho e Mão. Faculdade de Medicina da Universidade de São Paulo. Cap. 16, p. 184-89, set., 1991.

MATTHEWS, P.; RICHARDS, H. Factors in the adherence of flexor tendon after repair: An experimental study in the rabbit. Journal of Bone and Joint Surgery, London, v. 58-B, n 2, p. 230-36, May, 1976.

McDIARMID, T.; BURNS, P.N. Clinical applications of therapeutic ultrasound. Physiotherapy, London, v. 73, n. 4, p. 155-62, April, 1987.

McDIARMID, T.; BURNS, P.N.; LEWITH, G.T.; MACHIN, D. Ultrasound and the treatment of pressure sores. Physiotherapy, London, v. 71, n. 2, p. 66-7, 1985.

MENDONÇA, A. C. Estudo da regeneração do nervo ciático de rato submetido a estimulação elétrica após lesão por esmagamento. 2000. 68p. Dissertação (Mestrado) - Faculdade de Medicina de Ribeirão Preto/Escola de Engenharia de São Carlos, Universidade de São Paulo, Ribeirão Preto, 2000.

MENEZES, D.F.; VOLPON, J.B.; SHIMANO, A.C. Aplicação do ultra-som terapêutico em lesão muscular experimental aguda. Revista Brasileira de Fisioterapia, São Carlos, v.4, n.1, p.27-31, out., 1999.

MOURAD, P.D.; LAZAR, D.A.; CURRA, F.P.; MOHR, B.C.; ANDRUS, K.C.; AVELINO, A.M.; McNUTT, L.D.; CRUM, L.A.; KLIOT, M. ultrasound accelerates functional recovery after peripheral nerve damage. Neurosurgery, Baltimore, v. 48, n. 5, p. 1136-40, May., 2001.

MONTE RASO, V.V. Os efeitos do ultra-som terapêutico nas lesões por esmagamento do nervo ciático em ratos. 2002. 59p. Dissertação (Mestrado) Faculdade de Medicina de Ribeirão Preto/Escola de Engenharia de São Carlos, Universidade de São Paulo, Ribeirão Preto, 2002.

PEACOCK, E.E. Biological principles in the healing of long tendons. The Surgical Clinics of North America, Philadelphia, v. 45, n.2, p. 461-76, Apr.,1965.

PENNINGTON, D.G. The influence of tendon sheath integrity and vincular blood supply on adhesion formation following tendon repair in hens. British Journal of Plastic Surgery, Edinburgh, v. 32, n. 4, p. 302-6, Oct., 1979.

POPSPISILOVA, J. Effect of ultrasound on collagen synthesis and deposition in experimental granuloma tissue. Possibilities of clinical uses of ultrasound in healing disorders. Acta Chirurgiae Plasticae, Prague, v. 18, n. 4, p. 176-83, 1976.

POTENZA, A.D. Tendon healing within the flexor digital sheath in the dog. Journal of Bone and Joint Surgery, London, v. 44-A, n. 1, p. 49-64, Jan., 1962. 
ROBERTS, M.; RUTHERFORD, J.H,; HARRIS, D. The effect of ultrasound on tendon repairs in the rabbit. The Hand, Essex, v. 14, n. 1, p. 17-20, Feb., 1982.

ROTHKOPF, M.D.; WEBB, S.; SZABO, R.M.; GELBERMAN, R.H.; MAY, J.W.Jr. An experimental model for the study of canine flexor tendon adhesions. Boston. Journal of Hand Surgery, St. Louis, v. 16, n. 4, p. 694-700, Jul., 1991.

ROMANO, C.V.G. Os efeitos do ultra-som terapêutico aplicado na fase precoce da cicatrização do tendão flexor. Estudo biomecânico em tendões de coelhos. Ribeirão Preto. 2001. 54p. Dissertação (Mestrado). Escola de Engenharia de São Carlos/ Faculdade de Medicina de Ribeirão Preto, Universidade de São Paulo, Ribeirão Preto, 2001.

SOBANIA, L.C. Lesões dos tendões flexores. In: PARDINI JR, A.G., $2^{\mathrm{a}}$ ed. Traumatismos da mão. Rio de Janeiro. Editora Medsi, 1992, Cap. 9, p. 169-99.

STEVENSON, J.H.; PANG, C.Y.; LINDSAY, W.K.; ZUKER, R.M. Functional, mechanical, and biochemical assessment of ultrasound therapy on tendon healing in the chicken toe. Plastic and Reconstructive Surgery, Baltimore, v. 77, n. 6, p. 965 72, Jun., 1986.

Ter HAAR, G. Basic physics of therapeutic ultrasound. Physiotherapy, London, v.64, n. 4, p. 100-03, Apr. ,1978.

Ter HAAR, G. Basic physics of therapeutic ultrasound. Physiotherapy, London, v. 74, n. 3, p. 110-13, Mar., 1987.

TUREK, S.L. Ortopedia. Princípios e sua aplicação. $4^{\mathrm{a}}$ ed., São Paulo: Manole Ltda, 1991,v. 2, p. 1415.

TURNER, S.M.; POWELL, E.S. The effect of ultrasound on the healing of repaired cockerel tendon: is collagen cross-linkage a factor? Journal of Hand Surgery, St. Louis, v. 14b, n. 4, p. 428-33, Nov., 1989.

WATSON, M. The determinants of flexor tendon fibrosis following trauma: an experimental study in rabbits. The Hand, Essex, v. 10, n.2, p.150-53, Jun.,1978.

WILLIAMS, R. Production and transmission of ultrasound. Physiotherapy, London, v.73, n.3, p. 113-16, Mar., 1987.

YOUNG, S.R.; DYSON, M. Effect of therapeutic ultrasound on the healing of full thickness exciseal skin lesion. Ultrasonics. London, v. 28, n. 3, p. 175-80, May. 1990. 


\section{ANEXOS}

TABELA A - Valores individuais de cada animal para a variável: Aderência.

TABELA B - Valores individuais de cada animal para a variável: Proliferação de Fibroblastos.

TABELA C - Valores individuais de cada animal para a variável: Deposição de Colágeno.

TABELA D - Valores individuais de cada animal para a variável: Reação Inflamatória.

TABELA E - Valores individuais de cada animal para a variável: Microcalcificações.

TABELA F - Valores individuais de cada animal para a variável: Vascularização. 
TABELA A - Valores individuais de cada animal para a variável: Aderência.

\begin{tabular}{cccc}
\hline Animal & Grupo A & Grupo B & Grupo C \\
\hline $\mathbf{1}$ & 0 & 1 & 1 \\
\hline $\mathbf{2}$ & 1 & 2 & 3 \\
\hline $\mathbf{3}$ & 1 & 3 & 2 \\
\hline $\mathbf{4}$ & 0 & 2 & 3 \\
\hline $\mathbf{5}$ & 3 & 3 & 3 \\
\hline $\mathbf{6}$ & 0 & 2 & 2 \\
\hline $\mathbf{7}$ & 1 & 1 & 2 \\
\hline $\mathbf{8}$ & 3 & 2 & 3 \\
\hline $\mathbf{9}$ & 2 & 2 & 3 \\
\hline $\mathbf{1 0}$ & 3 & 2 & 3 \\
\hline
\end{tabular}

Valores:

ausente (0)

presença leve (1)

presença moderada (2)

presença acentuada (3) 
TABELA B - Valores individuais de cada animal para a variável: Proliferação de Fibroblastos.

\begin{tabular}{cccc}
\hline Animal & Grupo A & Grupo B & Grupo C \\
\hline $\mathbf{1}$ & 2 & 2 & 1 \\
\hline $\mathbf{2}$ & 2 & 2 & 2 \\
\hline $\mathbf{3}$ & 1 & 2 & 2 \\
\hline $\mathbf{4}$ & 2 & 1 & 1 \\
\hline $\mathbf{5}$ & 3 & 1 & 1 \\
\hline $\mathbf{6}$ & 2 & 2 & 1 \\
\hline $\mathbf{7}$ & 2 & 1 & 1 \\
\hline $\mathbf{8}$ & 3 & 2 & 1 \\
\hline $\mathbf{9}$ & 2 & 1 & 1 \\
\hline $\mathbf{1 0}$ & 2 & 1 & 1 \\
\hline
\end{tabular}

Valores:

ausente (0)

presença leve (1)

presença moderada (2)

presença acentuada (3) 
TABELA C - Valores individuais de cada animal para a variável: Deposição de Colágeno.

\begin{tabular}{cccc}
\hline Animal & Grupo A & Grupo B & Grupo C \\
\hline $\mathbf{1}$ & 1 & 1 & 2 \\
\hline $\mathbf{2}$ & 1 & 1 & 2 \\
\hline $\mathbf{3}$ & 1 & 1 & 3 \\
\hline $\mathbf{4}$ & 1 & 1 & 3 \\
\hline $\mathbf{5}$ & 1 & 3 & 3 \\
\hline $\mathbf{6}$ & 1 & 1 & 3 \\
\hline $\mathbf{7}$ & 1 & 1 & 2 \\
\hline $\mathbf{8}$ & 3 & 3 & 3 \\
\hline $\mathbf{9}$ & 3 & 3 & 3 \\
\hline $\mathbf{1 0}$ & 3 & 3 & 2 \\
\hline
\end{tabular}

Valores:

ausente $(0)$

presença leve (1)

presença moderada (2)

presença acentuada (3) 
TABELA D - Valores individuais de cada animal para a variável: Reação Inflamatória.

\begin{tabular}{cccc}
\hline Animal & Grupo A & Grupo B & Grupo C \\
\hline $\mathbf{1}$ & 0 & 0 & 0 \\
\hline $\mathbf{2}$ & 2 & 0 & 2 \\
\hline $\mathbf{3}$ & 0 & 0 & 1 \\
\hline $\mathbf{4}$ & 0 & 0 & 0 \\
\hline $\mathbf{5}$ & 0 & 1 & 0 \\
\hline $\mathbf{6}$ & 0 & 0 & 0 \\
\hline $\mathbf{7}$ & 0 & 2 & 0 \\
\hline $\mathbf{8}$ & 1 & 2 & 0 \\
\hline $\mathbf{9}$ & 0 & 0 & 1 \\
\hline $\mathbf{1 0}$ & 3 & 0 & 0 \\
\hline
\end{tabular}

Valores:

ausente $(0)$

presença leve (1)

presença moderada (2)

presença acentuada (3) 
Tabela E - Valores individuais de cada animal para a variável: Microcalcificações.

\begin{tabular}{cccc}
\hline Animal & Grupo A & Grupo B & Grupo C \\
\hline $\mathbf{1}$ & 0 & 0 & 0 \\
\hline $\mathbf{2}$ & 0 & 0 & 0 \\
\hline $\mathbf{3}$ & 0 & 0 & 0 \\
\hline $\mathbf{4}$ & 0 & 0 & 0 \\
\hline $\mathbf{5}$ & 0 & 0 & 0 \\
\hline $\mathbf{6}$ & 0 & 0 & 0 \\
\hline $\mathbf{7}$ & 0 & 0 & 0 \\
\hline $\mathbf{8}$ & 0 & 0 & 0 \\
\hline $\mathbf{9}$ & 0 & 1 & 0 \\
\hline $\mathbf{1 0}$ & 1 & 1 & 0 \\
\hline
\end{tabular}

Valores:

ausente (0)

presente (1) 
TABELA F - Valores individuais de cada animal para a variável: Vascularização.

\begin{tabular}{cccc}
\hline Animal & Grupo A & Grupo B & Grupo C \\
\hline $\mathbf{1}$ & 0 & 2 & 1 \\
\hline $\mathbf{2}$ & 0 & 0 & 1 \\
\hline $\mathbf{3}$ & 0 & 0 & 1 \\
\hline $\mathbf{4}$ & 0 & 0 & 0 \\
\hline $\mathbf{5}$ & 0 & 0 & 2 \\
\hline $\mathbf{6}$ & 0 & 0 & 2 \\
\hline $\mathbf{7}$ & 0 & 0 & 2 \\
\hline $\mathbf{8}$ & 0 & 2 & 1 \\
\hline $\mathbf{9}$ & 1 & 1 & 1 \\
\hline $\mathbf{1 0}$ & 2 & 0 & 0 \\
\hline
\end{tabular}

Valores:

presença normal (0)

presença aumentada (1)

presença aumentada (2) 